\author{
Federal Reserve Bank of New York \\ Staff Reports
}

\title{
How Mortgage Finance Affects the Urban Landscape
}

\author{
Sewin Chan \\ Andrew Haughwout \\ Joseph Tracy
}

Staff Report No. 713

February 2015

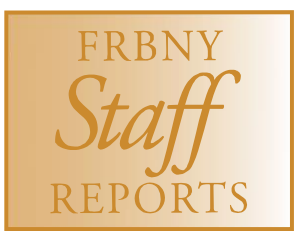

This paper presents preliminary findings and is being distributed to economists and other interested readers solely to stimulate discussion and elicit comments. The views expressed in this paper are those of the authors and do not necessarily reflect the position of the Federal Reserve Bank of New York or the Federal Reserve System. Any errors or omissions are the responsibility of the authors. 


\author{
How Mortgage Finance Affects the Urban Landscape \\ Sewin Chan, Andrew Haughwout, and Joseph Tracy \\ Federal Reserve Bank of New York Staff Reports, no. 713 \\ February 2015 \\ JEL classification: G21, R31, R21
}

\begin{abstract}
This chapter considers the structure of mortgage finance in the U.S., and its role in shaping patterns of homeownership, the nature of the housing stock, and the organization of residential activity. We start by providing some background on the design features of mortgage contracts that distinguish them from other loans, and that have important implications for issues presented in the rest of the chapter. We then explain how mortgage finance interacts with public policy, particularly tax policy, to influence a household's decision to own or rent, and how shifts in the demand for owner-occupied housing are translated into housing prices and quantities, given the unusual nature of housing supply. We consider the distribution of mortgage credit in terms of access and price, by race, ethnicity, income, and over the lifecycle, with particular attention to the role of recent innovations such as non-prime mortgage securitization and reverse mortgages. The extent of negative equity has been unprecedented in the past decade, and we discuss its impact on strategic default, housing turnover, and housing investment. We describe spatial patterns in foreclosure and summarize the evidence for foreclosure spillovers in urban neighborhoods. Finally, we offer some thoughts on future innovations in mortgage finance.
\end{abstract}

Key words: mortgage, cities

Chan: New York University (e-mail: sewin.chan@nyu.edu). Haughwout, Tracy: Federal Reserve Bank of New York (e-mail: andrew.haughwout@ny.frb.org, joseph.tracy@ny.frb.org). The authors thank Shaopeng He, Sean Capperis, Neha Hridaya, and Samuel Kapon for assistance with the figures and bibliography. They also thank Karen Pence, Stijn van Nieuwerburgh, and Will Strange for their helpful comments. The views expressed in this paper are those of the authors and do not necessarily reflect the position of the Federal Reserve Bank of New York or the Federal Reserve System. 


\section{How Mortgage Finance Affects the Urban Landscape}

Over 80 percent of Americans live in metropolitan areas, and housing is the dominant land use in cities. For many Americans, homeownership is an important goal, and a substantial majority of the population, including renters, believes that homeownership is a good way to improve their financial situation (Fannie Mae, 2013). For many owners, and for the great majority of renters, purchasing a home will mean obtaining a mortgage. For this reason, the availability and form of mortgages is an important determinant of the homeownership rate, which in turn affects the nature of the housing stock and the organization of residential activity within and across metropolitan areas.

In this chapter, we consider the literature on mortgage finance in the U.S. and its role in shaping the urban landscape. The 2000s witnessed an enormous boom/bust cycle in the residential real estate market, followed by the sharpest contraction in the overall economy since the 1930s. These events, which are widely thought to have been driven at least in part by the mortgage market, had a pronounced spatial pattern which research is only beginning to completely understand. Our workhorse models of local demand and supply of owner-occupied housing can give us only partially satisfactory explanations for the patterns we observe in the data, and more work, both theoretical and empirical, is needed to understand why the boom/bust cycle occurred when and where it did. For example, the user cost framework that has long served as the basis for analyzing how credit conditions affect the demand for owner-occupied housing provides a good basis for understanding the direction of demand shifts during the boom, but the basic model requires significant extensions to capture the magnitude and locational patterns of the demand volatility we observed during the 2000s. 
Similarly, the decade produced some challenges for our understanding of how demand shifts are translated into prices and quantities. Why did prices rise so much in housing markets that by most measures featured relatively elastic supply? The role of expectations and buyers with motivations other than owner occupancy are beginning to play important roles in understating these dynamics. Another key set of questions concerns the spatial distribution of credit and its effects on the spatial dimensions of the boom and bust within metro areas. The long tradition of studies on the basic question of access to credit is undergoing a revival, this time with a special emphasis on nonprime credit. There is still much to learn on this topic, although our understanding in this area is constrained by inadequate data.

Finally, the enormous wave of foreclosures that followed the bust in housing prices featured spatial patterns that were perhaps even stronger than those found for lending in the boom. We are only now beginning to understand the complex dynamics of neighborhood housing prices under conditions of market distress, and work is likely to continue on this front for many years.

Our discussion begins with a description of the evolution of the mortgage contract and its salient features. In section 2, we provide an analysis of the way that mortgage finance interacts with public policy - particularly the tax code - to influence the rent-own choice. How shifts in the relative demand for owner-occupancy are translated into housing prices and quantities requires understanding the unusual nature of housing supply, a topic which we also discuss in section 2 . Section 3 discusses the distribution of mortgage credit in metropolitan areas, across both geographies and demographics. Important innovations in recent years - nonprime mortgage securitization and reverse mortgages - have substantially influenced access to credit within metropolitan areas, and have therefore had significant real impacts as well. An important feature of mortgages as they currently exist in the U.S. is that they do not have margin calls. For this reason, a decline in house prices can put borrowers in negative equity, a situation which has many potential 
consequences that we discuss in section 4 . One of the most significant implications of house price declines is foreclosure, a phenomenon which has become enormously important in many metropolitan areas in the last decade. Section 5 discusses reasons for spatial patterns in foreclosures, and summarizes evidence for the "spillovers" associated with foreclosures in urban neighborhoods. Section 6 provides a brief summary of potential reforms to mortgage contracts, and points to future research directions.

\section{Mortgage finance in the United States}

Most homeowners finance their purchases with a mortgage. For the great majority of homeowning families, the house is a very significant part of their wealth, and the availability of mortgage credit allows households to smooth their consumption rather than save for many years to buy a home with cash. For example, a household with the 2012 median income of \$53,046 would need to save nearly three and one-half years' worth of income to purchase the median-valued owneroccupied housing unit, which was valued at $\$ 181,400{ }^{1}$ At a saving rate of 20 percent per year, this household would save about $\$ 10,600$ per year, which (assuming an annual return on the savings of 5 percent) would allow the household to purchase the home after thirteen years (assuming no change in income or house prices); savings at the national average rate of 4.5 percent of income would require 33 years to develop a fund large enough purchase the house.

Mortgage credit allows the household to purchase its home with far less of an up-front consumption sacrifice. Assuming mortgage interest rates of 5 percent per annum, the median

\footnotetext{
${ }^{1}$ Median values from the U.S. Census, 2008-12 averages.
} 
income household could qualify for a mortgage to buy the median house after saving a 20 percent down payment of $\$ 36,280$. This would take a little over three years with a saving rate of 20 percent of income each year. The household will be paying back the loan for the next 30 years, but will be doing so while enjoying the benefits of homeownership rather than looking forward to them.

Figure 1 displays the homeownership rate over time and Figure 2 shows the prevalence of mortgage finance in recent years. The significant (albeit apparently temporary) rise in the homeownership rate during the housing boom of the late 1990s and early 2000s was associated with a very substantial increase in mortgage credit, underscoring the important relationship between the two series. In this section we describe important features of mortgages in the U.S., and discuss how they affect important outcomes in the housing market and the risks they pose.

\subsection{Important design features of mortgage finance}

For historic and institutional reasons, mortgage finance in the U.S. has features that distinguish them from other loans. The mortgage market has long featured a prominent role for both explicit and implicit government influence, from support for long-term, fixed-rate mortgage contracts to limits on the ability of lenders to pursue deficiency judgments against borrowers who default on the mortgage contract. All of these features have effects on the costs and benefits of borrowing and lending in the mortgage market, and we outline the most salient of them below.

\subsubsection{Collateral}

Collateralized loans stipulate an interest rate or schedule of rates, and margin requirements. The margin requirements consist of an initial margin and possibly a maintenance margin. The initial margin determines the degree to which the loan is over-collateralized at the outset. This provides

protection to the lender in the event of a decline in the value of the collateral. A maintenance margin 
requirement specifies a minimum margin that the borrower must maintain over time. If the borrower fails to make a margin call then the lender can call the loan. The combination of initial and maintenance margin requirements can significantly limit the possibility that the loan becomes "under water" where the value of the collateral is less than the outstanding loan balance.

Mortgages have the feature that they only specify an initial margin - the down payment percentage - which determines the initial loan-to-value (LTV) ratio. Since there is no maintenance margin requirement on mortgages, if house prices decline subsequent to the mortgage origination, the borrower's equity is reduced and can become negative. As a consequence, negative equity is a more important consideration for mortgages than for other types of collateralized loans.

An alternative to a maintenance margin is to have mortgages with short terms. For example, the typical Canadian mortgage has a term of 5 years. ${ }^{2}$ The borrower must roll-over the mortgage at expiration. At the roll-over date, a borrower must re-establish at least the minimum required level of equity. A downside to maintenance margins, or equivalently to short mortgage terms, is that the borrower may not be able to post the additional margin (and therefore cannot roll-over the loan) and is forced into a sale or a default. This can lead to "fire sales" and place further downward pressure on prices. ${ }^{3}$ Lea (2010) provides data showing that short- or medium-term mortgages of the Canadian type are common in OECD countries, relative to longer term fixed-rate mortgages. The U.S. is distinguished by having a very large market share for long-term, fixed-rate mortgages. This will have implications for how the housing and mortgage markets react in times of stress.

The absence of a maintenance margin can create an asymmetry between the current owner and a potential new owner with regard to equity. If house prices decline pushing the current LTV

\footnotetext{
${ }^{2}$ One of the factors that impacts the short-term is that a high fraction of mortgages are funded through deposits and that deposit guarantees in Canada cover terms up to 5 years. See Kiff (2009). ${ }^{3}$ This roll-over risk from short-term mortgages was a significant problem in the U.S. during the Depression and led to the development of long-term amortizing mortgages offered by the Federal Housing Administration. See Green and Wachter (2005).
} 
below the minimum requirement at origination, the current owner by simply making the required monthly mortgage payments can continue to live in the house without adding additional equity. However, a potential new owner would have to satisfy the minimum LTV requirement. This means that a new owner would have to put more equity into the house than the existing owner currently has in the house. In this situation, the current owner would also have to put in additional cash in order to move to an equivalently priced home (abstracting from selling costs). This creates an incentive for the current owner to set a higher list price for the house even if this means taking a longer time to sell. Genesove and Mayer (1997) find evidence for this effect in the Boston condo market in the early 1990 s.

For long-term mortgages, lenders should set the initial margin based on the perceived degree of house price risk. To maintain a relatively constant risk of negative equity, mortgage lenders would need to require a larger down payment percentage during periods when, or in locations where, house prices have a higher volatility. Evaluating whether this occurs in practice is difficult because we do not have data on the time-series of beliefs by mortgage lenders regarding house price risk. ${ }^{4}$ However, as shown in Table 1, the distribution of initial LTVs rose during the height of the most recent housing boom from 2004 to 2006.

\subsubsection{Lien Priority}

A borrower may take out more than one loan that is collateralized by the same house. In this case, the lien priority is important in determining the order in which creditors have a claim on the proceeds from a sale of the house. The lien priority typically is based on the date in which the lien was recorded with the county, rather than the date that the loan was originated. That is, the earliest

\footnotetext{
${ }^{4}$ For an interesting discussion on the heterogeneity of beliefs regarding the housing market during the boom see Gerardi et al (2010).
} 
recorded existing lien has the top priority. ${ }^{5}$ This voluntary recording system provides a strong incentive for creditors to pay the recording fee in a prompt manner. However, the lien priority can create a potential friction for interventions aimed at assisting distressed borrowers. For example, consider a program that facilitates negative equity borrowers to refinance their mortgage and thus reduce their monthly payments. ${ }^{6}$ For borrowers with multiple liens, the lender with the first-lien that is participating in this program would not want to do the refinance if this required giving up their first-lien position. Typically, the second-lien holders would have to agree to re-subordinate their lien behind the refinanced mortgage in this case. ${ }^{7}$ But if the borrower's combined LTV across the firstand second-liens was low enough, then this friction disappears. In this case, the borrower could refinance by paying off all loans and credit lines secured by the house and replace them with a single refinanced mortgage.

\subsubsection{Recourse}

Mortgage loans can be either non-recourse or recourse. Where mortgages are non-recourse, the lender only has claim to the sale proceeds from the house to satisfy the balance due on the mortgage. In contrast, where mortgage loans are recourse, if the proceeds from the sale do not fully pay off the balance on the mortgage, then the lender can file for a deficiency judgment against the borrower. The deficiency judgment allows the lender to use the borrower's other financial assets to pay off the remaining balance on the mortgage. Recourse varies by state, and for a few states by the

${ }^{5}$ Exceptions to this rule are tax liens for unpaid property taxes which have super priority regardless of the filing date.

${ }^{6}$ Absent a special program, negative equity borrowers face a financial friction to refinancing in that they must have the financial resources to both fully pay off the existing mortgage and put a down payment on the refinance mortgage. See Caplin et al (1997b) for estimates of the degree to which declining house prices can generate a friction to refinancing.

${ }^{7}$ States can allow for "equitable subrogation" where the first-lien holder does not need an agreement from second-lien holders to re-subordinate so long as a refinance of the first-lien does not disadvantage the junior lien holders. Bond et al (2013) find that states with equitable subrogation experienced a higher refinance rate holding other factors constant. 
type of mortgage. This variation in the degree to which lenders are able to collect deficiencies appears to be unique to the U.S. In Lea's (2010) study of 12 developed countries, in all of the other countries mortgages are recourse and lenders typically pursue borrowers for deficiencies. Recourse may affect a borrower's behavior prior to a default as well as during a foreclosure. ${ }^{8}$

\subsubsection{Assumability and portability}

Typically, mortgage loans in the U.S. are neither assumable nor portable. ${ }^{9}$ A mortgage is assumable if the borrower can transfer the mortgage to the buyer upon the sale of the property, but the buyer must still meet the underwriting guidelines of the lender. If a mortgage is portable, then a borrower who sells and buys a property can transfer the existing mortgage to the new property, so long as the new property provides adequate collateralization for the mortgage. That is, upon the sale of the property with an assumable mortgage the lender may end up retaining the collateral and reunderwriting a new borrower. In contrast, with a portable mortgage the lender may end up retaining the borrower and re-underwriting the collateral. As we will discuss, the fact that conventional mortgages typically are neither assumable nor portable becomes important for fixed-rate mortgages (FRMs) in a rising interest rate environment.

\subsubsection{Mortgage term}

Another feature of most U.S. mortgages is that they have long terms. This is important given that the housing collateral backing up the mortgage is a depreciating asset, where the rate of

\footnotetext{
${ }^{8}$ Ghent and Kudylak (2011) find that on average, U.S. borrowers are 30 percent more likely to default in non-recourse states. Jones (1993) finds for a sample of Canadian mortgages originated in Alberta and British Columbia between 1982 and 1986 that recourse reduces the incidence of strategic default.

${ }^{9}$ An exception is Federal Housing Administration (FHA) mortgages which are assumable. . In Canada, mortgages are portable and in Alberta and British Columbia they are also assumable (Traclet, 2010 and Crawford et al, 2013). However, their short-terms limit the value of this option. Mortgages in Denmark are also assumable (Green and Wachter, 2005).
} 
depreciation depends on actions taken by the borrower. An important offset to the depreciation rate is the extent to which the borrower makes costly investments in maintenance and improvements (hereafter housing investments) to the house. These expenditures typically are significant as measured relative to the value of the property. Gyourko and Tracy (2006) using American Housing Survey (AHS) data from 1985 to 1993 report an average expenditure level of \$2,889 (in 2012 dollars), or 1.7 percent of the reported house value. Haughwout et al (2013) using Consumer Expenditure Survey data from 2007 to 2012 report a mean expenditure of $\$ 3,152$ (in 2012 dollars), or 1.4 percent of the house value. In aggregate, over the past 20 years these housing investments averaged 45 percent of the value of new home construction. Maintaining incentives over time for the borrower to continue to make these costly investments is important for sustaining the value of the collateral.

\subsection{Withdrawing home equity}

Over time a lender is typically protected by the build up of equity through amortization of the loan balance and house price appreciation. However, in most cases the lender cannot prevent the borrower from withdrawing this additional equity. This can expose the lender to risks even though the lender retains lien priority.

There are three separate ways that owners may borrow against their home equity to convert it into cash available for consumption or other purposes (Greenspan and Kennedy, 2008). The first is by refinancing their first-lien mortgage through a "cash-out" refinance. Here, a homeowner pays off their previous mortgage with the proceeds of a new, larger, mortgage. The difference between the balances on the two mortgages is available to the borrower as cash at settlement, and the borrower may use those proceeds as she likes, without restriction. Note that refinancing in this way 
will typically result in a new set of scheduled payments that are, in the early years of the contract, predominately interest, which as we will discuss is tax deductible.

The other methods of using home equity as collateral for borrowing involve either junior liens, or a reverse mortgage, which we describe later. There are two forms of junior liens: closed end seconds (CES) and home equity lines of credit (HELOCs). A CES is a junior lien installment loans that has the same form as first mortgages. They deliver a fixed amount of upfront cash to the borrower, and have a fixed term over which principal and interest are repaid to the lender. In contrast, HELOCs are revolving instruments that are more like credit cards. HELOCs typically have a borrowing limit, related to the total available housing equity, which the homeowner can utilize as she wishes during the "draw" period, typically ten years. ${ }^{10}$

Junior liens, especially HELOCs, were an important part of the run-up in debt secured by housing during the boom. Aggregate HELOC balances are considerably larger than CESs and are typically held by borrowers with higher credit scores (Lee, Mayer and Tracy, 2013). Figure 3 shows the evolution of mortgages (including both first-liens and CESs) and HELOC balances between 2003 and 2013. HELOC balances rose almost three fold from $\$ 242$ billion at the start of 2003 to over $\$ 714$ billion in 2009 . Since 2009 , HELOC balances have steadily declined and they stood at $\$ 529$ billion at the end of 2013 .

Borrowers may put the proceeds from junior liens to many purposes. Junior liens may be used to increase leverage at the purchase of a new home (Greenspan and Kennedy, 2008 and Lee, Mayer and Tracy, 2013). At the peak of the housing boom in 2006, nearly half of all home purchases in locations like Las Vegas and Miami involved second-liens. So-called "subsequent seconds" junior liens added after the home purchase when the borrower has built some equity through the

\footnotetext{
${ }^{10}$ At "end-of-draw," no further borrowing is allowed. At that point, HELOCs begin to amortize and become more similar to variable rate closed-end mortgages. As of this writing many HELOCs originated during the boom years are beginning to enter the end-of-draw period.
} 
combination of amortization and rising home values - can be used for virtually any purpose, from remodeling the home, financing a college education, paying down unsecured credit balances or taking a vacation (Mian and Sufi 2011).

One important potential use of CESs and HELOCs is to allow equity extraction for the purpose of financing small business startups, potentially supporting employment growth in localities that experience house price growth. New small businesses are considered too risky to attract either bank financing or outside equity financing. Entrepreneurs, then, must self-finance the business initially in order to establish a track record. In an influential paper, Hurst and Lusardi (2004) report that entry rates into small business ownership are not related to household wealth, including housing wealth, for the great majority of the wealth distribution. More recent work has suggested that controlling for whether the transition to self-employment is planned re-establishes the connection between wealth and entrepreneurship. Of particular importance for our purposes is empirical evidence that house price appreciation is positively related to small business formation (Fairlie and Kaminsky, 2012; Harding and Rosenthal, 2013). As discussed further below, this suggests that markets with inelastically supplied housing will potentially have higher rates of entrepreneurship. This is an area for future research.

\section{How mortgage finance affects the market for owner-occupied housing}

Because housing is such a large purchase, representing multiple years of income for most families, households making the transition to homeownership must either make very significant consumption sacrifices in advance of the purchase, or use credit. As a consequence, mortgages play a large role in the transition from renting to owning. Overall credit conditions, and their 
manifestation in the mortgage market, thus become an important determinant of the level of demand for owner-occupied, relative to rental, housing. In this section, we present simple models of the demand and supply sides of the housing market that are most prevalent in the current literature. Having the rudiments of a model in mind will facilitate our discussion of how various features of the mortgage contract and its treatment in tax policy affect real outcomes like prices and quantities of housing transacted and homeownership rates.

\subsection{The demand for owner-occupied housing}

We begin with the demand for owner-occupied housing units. Since everyone must consume housing services, our focus is on factors that affect the relative attractiveness of owning versus renting. Here, two features of the mortgage contract are very important. The down payment requirement determines the maximum mortgage that is available to purchase a house of given value, while the mortgage interest rate determines the annual cost of that borrowing. In addition to prevailing mortgage terms like interest rates and down payment requirements, several other costs and benefits of ownership affect the demand for owner-occupancy relative to rental units.

Public policy, particularly the tax code, treats homeownership as a special category of investment. To see how this works, it is helpful to contrast the tax treatment of owner-occupancy to that afforded to rental properties. The two forms of tenure are directly analogous as we will explain. In each case, we have a landlord who owns the property and a tenant who occupies the unit and pays rent to the landlord. This is obvious for the case of a rental property. In the case of the owneroccupied property, the landlord and the tenant roles still both exist but they now are the same person and the rental payment is implicit, but in principle the situations are identical. Nonetheless, the treatment of these two situations under the personal income tax is quite different. The owner of the rental property will pay income taxes on the difference between the rent payments she receives 
and the costs of owning the property (mortgage interest, property taxes, maintenance and depreciation). The analogous treatment would have homeowners paying taxes on the difference between the rental income they (implicitly) pay themselves and the costs of owning the property. Instead, homeowners are allowed to exclude from income both the expenses, as a regular landlord would, and the implicit rental income they pay to themselves. In this section, we discuss the tax code's implications for the relationship between mortgage finance and housing market outcomes.

Besides the exclusion of implicit rental income, additional tax benefits to homeownership come in the forms of the exclusion of most housing-related capital gains, and the deductibility of state and local property taxes from federal income taxes. These tax expenditures are expected to cost the Treasury $\$ 80, \$ 57$ billion and $\$ 34$ billion, respectively, in fiscal year 2015 (OMB 2014, p. 206). While the subsidies are not directly tied to the form of finance - i.e., they do not directly affect the mortgage market - they nonetheless potentially reduce the after-tax cost of buying a home, and thus will likely increase the demand for all forms of financing, including mortgage borrowing. Thus these tax advantages interact with the preferential treatment of mortgage interest, described below, to potentially affect the ownership, form and location of the housing stock in metropolitan areas. Poterba and Sinai (2008) offer a detailed analysis of the incidence of benefits from various elements of the tax treatment of owner-occupied housing.

The U.S. is not alone in providing support for owner occupancy in its tax code. In a survey of OECD countries, Bourassa and Grigsby (2000) find that only two (The Netherlands and Sweden) tax housing capital gains. Among the sample of 24 countries surveyed by Bourassa et al (2013), only three - Poland, The Netherlands and Switzerland - tax the full implicit stream of rental payments. Among those 24 countries the mortgage interest deduction is quite common, with at least partial deductibility available in 14 of the countries. 
In addition to the tax benefits afforded to owner occupancy in the U.S., the rules of many other financial transactions favor owner-occupied housing, including exclusion of housing from personal bankruptcy proceedings, estate taxes and from the calculation of assets for programs such as Medicaid and student loans (Morgan et al 2012). While these preferences are also independent of the mortgage contract, their value increases with the size and value of the house, which, as described below, is likely increased by the deductibility of mortgage interest. Because they affect the after-tax cost and benefits of owning versus renting, all of these various subsidies to owner occupancy have the potential to affect the location of the housing demand curve.

One of the principal features of public policy that affects the net cost of credit to mortgage borrowers is the deductibility of mortgage interest from federally taxable income. Current federal tax law allows homeowners to deduct mortgage interest for loans up to $\$ 1,000,000$ used to buy, build or improve the housing unit in which they live or one other unit. In addition, interest paid on other loans up to $\$ 100,000$ secured by these properties, for example HELOCs may be deducted, regardless of the purpose to which these monies are put. This tax expenditure is among the largest in the Internal Revenue Code, and is expected to cost the Treasury \$74 billion in FY 2015 (OMB 2014, p. 206). As a practical matter, this tax benefit reduces the cost of mortgage and HELOC interest to the borrower, with the value of the benefit depending on the borrower's marginal tax rate, so long as the borrower's deductions exceed the standard deduction threshold. For a borrower in the top bracket who faces a 35 percent marginal rate, an additional $\$ 100$ of mortgage interest reduces tax liability by $\$ 35$, while a borrower in the 15 percent bracket would receive only $\$ 15$. In addition to this federal income tax preference, 34 states also offer at least partial deductibility of mortgage interest. Hilber and Turner (2014) document the extent of these state preferences, which vary substantially over states. 
The favorable treatment of mortgage interest in the tax code is a benefit of debt-financed owner-occupancy that has attracted much attention from housing and public finance economists. In addition to providing incentives for homebuyers with income tax liabilities to borrow for their home purchases, thereby increasing the demand for mortgage credit, these reductions in the cost of borrowing for residential real estate have the effect of shifting the housing demand curve upward. Reduced after-tax interest costs reduce the user cost of housing, making debt-financed owneroccupied housing more attractive relative to other goods. Moreover, larger houses (mortgages) are relatively more attractive since the dollar value of the deduction rises with the interest paid. As we will discuss, the economic incidence of these tax benefits depends importantly on the supply elasticity in the local housing market.

Other features of the mortgage contract itself may also act as housing demand curve shifters. For example, reducing the down payment requirement from 20 percent of the purchase price to 10 percent means that buyers can either purchase the same home with a smaller amount of savings, or buy a larger (more expensive) home with the same down payment.

This effect is amplified at low mortgage interest rates. Himmelberg et al (2005) demonstrate the importance of mortgage interest rates in affecting the location of the housing demand curve, emphasizing the non-linearity of the relationship between interest rates and prices. Glaeser et al (2013) examine virtually all elements of the mortgage, from interest rates to down payment requirements, to explore the effect of these features on housing demand.

An additional benefit to homeownership comes through the credit market. Liquidityconstrained households may prefer to borrow to smooth consumption. For example, young people may wish to consume part of their (higher) permanent income today rather than to wait until they actually get the pay raise they expect. Access to, and the cost of, credit are crucial determinants of the ability of such households to smooth consumption. Unsecured credit - collateralized only by the 
borrower's promise to repay the debt - offers the potential to solve this problem, but given the existence of a default (bankruptcy) option for the borrower, the lender is uncertain that the loan amount will be repaid. In equilibrium, therefore, unsecured lending reflects the cost to the lender of the borrower's default option (Chatterjee et al, 2007). Other than housing equity, household access to secured credit is quite limited; it is primarily available to finance the purchase of certain specific consumer durables, like automobiles and, in some cases, large appliances.

Because HELOCs and CESs are secured by liens on real property, lenders are generally willing to provide this credit at interest rates considerably below that available for unsecured products like credit cards (Chatterjee et al 2007). In addition to the interest rate discount that junior liens carry, interest paid on junior liens, like that on first-liens, is exempt from federal income taxes up to a high limit. Owners will have access to this credit while renters will not; owners of larger homes will be able to borrower more than those with smaller homes. In this way, as well as in the fact that the value of the mortgage interest tax deduction increases with income, these aspects of housing finance will be related to inequality in urban areas.

\subsection{The effect of demand shifts on price and quantity}

We now turn our attention to the supply side of the housing market, which will allow us to complete our discussion of how demand shifts driven by changes in mortgage finance and its aftertax cost will affect prices and quantities in local areas.

Housing's durability has important implications for the way that demand changes, and thus features of housing finance, will affect prices and quantities. In particular, housing supply is nearly

completely inelastic at the current stock of housing for prices below replacement costs (Glaeser and Gyourko, 2005). That is, once units are built, downward shifts in demand have little effect on the 
number of units in place, since those units depreciate only slowly. ${ }^{11}$ Instead, downward shifts in the demand for housing will be reflected largely in (reduced) prices for housing.

Reductions in demand have little effect on market-clearing quantities in local housing markets, but markets can differ in how upward shifts in demand affect quantities. Glaeser et al (2008) explore how shifts in housing demand manifest themselves in different markets, depending on the supply elasticity in each market. Their model predictions are that any increase in demand, whatever the cause, will result in higher prices but only modest or negligible quantity effects in markets where housing is inelastically supplied. In contrast, in markets with relatively elastic supply, demand increases should result in new residential investment and less of a price response.

Figure 4 depicts the Glaeser et al view of the housing market during a boom phase, or one in which the cost or availability of mortgage credit becomes more favorable. Two possible kinds of markets are simultaneously depicted in the figure. Initially, demand is represented by demand curve $\mathrm{D}_{0}$, and the built housing stock is $\mathrm{H}_{0}$. Equilibrium is shown as point $\mathrm{A}$, with prices $\mathrm{P}_{0}=\mathrm{c}$, where $\mathrm{c}$ is the marginal cost of construction. Now consider an expansion of credit or a reduction in the cost of mortgage finance that shifts the demand curve up to $\mathrm{D}_{1}$. In a market with perfectly inelastic supply, represented by $\mathrm{S}(\mathrm{I})$, the new equilibrium is given by point $\mathrm{B}$ : there is no supply response and prices rise sharply, to $\mathrm{P}_{1}(\mathrm{I}){ }^{12}$ In contrast, in a market where supply elasticity is positive, new building is feasible and the supply schedule is assumed to be upward sloping as depicted by the segment labeled $\mathrm{S}_{1}(\mathrm{E})$. In the new equilibrium in this elastic market, point $C$, prices rise to $\mathrm{P}_{1}(\mathrm{E})$ and quantity supplied increases to $\mathrm{H}_{1}$.

\footnotetext{
${ }^{11}$ The rate of physical depreciation of housing is an area that is under-researched. A complication in estimating the depreciation rate is accounting for maintenance efforts by the owners. We discuss maintenance later in the chapter. See Harding et al (2007) for an extensive discussion and estimation using AHS data.

${ }^{12}$ Gyourko and Molloy (2014) explain how local government regulations can reduce the elasticity of housing supply.
} 
It is worthwhile to reiterate that the durability of housing produces stark asymmetries in the effects of demand shifts on local housing markets. Continuing our previous example, if mortgage conditions change such that demand shifts back to its original position, there will be different effects in these two markets. The inelastic market, still at supply $\mathrm{H}_{0}$, reverts back to point $\mathrm{A}$, the original equilibrium. In the elastically supplied market, however, the credit boom has induced an increase in built supply to $\mathrm{H}_{1}$, and the downward shift in demand reduces prices to $\mathrm{P}_{2}(\mathrm{E})$ - a level lower than the pre-boom equilibrium and below replacement cost. As fundamental demand begins to expand in the elastic supply market, prices will adjust upward, but there will initially be no new building activity. Once prices have recovered to the replacement cost, new supply will again be added to the market. Overbuilding to the extent that it occurs has important consequences for local housing markets.

An extension of the Glaeser et al view of durable housing supply is provided in Figure 5. Following Goodman (2013), we allow the possibility for owners and landlords to decide to abandon property. Abandoned property can lead to vandalism and stripping of any valuable materials from the property. This rapid deterioration in the quality of the property can result in local governments deciding to demolish the structure. In this way, some elasticity is reintroduced to housing supply at very low prices.

To explore this possibility, consider the case where housing demand declines from $\mathrm{D}_{0}$ to $\mathrm{D}_{1}$. The price of housing declines from $\mathrm{P}_{1}$ to $\mathrm{P}_{2}$. Assume, however, that at $\mathrm{P}_{2}$ the rental value of the property is sufficient to cover the variable cost to keeping the property. In this case, housing supply remains unaffected and all of the adjustment to the adverse demand shock occurs through the price of housing. Now assume that the adverse demand shock is more severe and demand declines from $\mathrm{D}_{0}$ to $\mathrm{D}_{2}$. At the existing supply of housing, $\mathrm{H}_{0}$, the price of housing would decline by enough to push the rental value below the variable cost for many landlords. These landlords face a "shut- 
down" decision much like managers of a firm. If the rental value does not cover the variable cost of having a tenant in the property, then the landlord will choose instead to leave the property vacant. If demand is not expected to improve, then this will lead to the property being abandoned. This shutdown decision reintroduces some elasticity of supply at very low prices that reflects the distribution of these variable costs of utilizing a property. ${ }^{13}$ This acts to reduce the downward pressure on prices from the adverse demand shock. Goodman (2013) documents that this segment of the housing supply curve has been important for cities such as Detroit which has experienced a 34 percent decline in its housing supply from 1970 to 2010.

The durability of housing thus implies that credit cycles will have real, long-lived implications that will differ across metropolitan areas depending on their supply elasticity. In particular, markets where housing is elastically supplied (on the upside) will be affected by a credit boom and bust both through a cycle of residential investment activity as well as consumption swings related to housing wealth effects. In contrast, inelastic markets will see credit conditions reflected almost exclusively in prices and therefore consumption related wealth effects, with fewer real effects from residential investment. Both will be adversely impacted by debt overhang problems following the bust (Mian and Sufi, 2009).

Glaeser et al test the predictions of this model using the proxy for housing supply elasticity developed in Saiz (2008). ${ }^{14}$ However, they note that several of the markets that experienced the largest booms in the recent cycle have high measured supply elasticities. These markets also demonstrated little variability of prices relative to replacement costs prior to the recent cycle. While having an elastic housing supply limits the likelihood of a serious housing bubble in a local market, it clearly does not prevent one from happening.

${ }^{13}$ The degree of this elasticity depends among other factors on the length of time captured by the supply curve. The longer the time period the greater the elasticity all else the same.

${ }^{14}$ This proxy is the percent of land within a 50 kilometer radius area that has a slope of less than 15 degrees. 
We are now in a position to explore how the determinants of the demand for housing described above will interact with supply to generate the prices and quantities of housing in different markets. Each of the factors discussed above - the favorable tax treatment accorded to owneroccupied homes, the fact that home equity provides a ready source of collateral to finance consumption and investments, the sheltering of home equity from various asset tests - serves to increase the attractiveness of owner-occupied relative to other assets, and thus shift the demand for housing upward. While intuition might suggest that this will necessarily lead to higher homeownership and larger houses, it is now clear that the effects of this demand shift will depend on the supply side of the market as well.

As the above discussion of the supply side of the housing market suggested, the effect of demand shifts induced by changes in mortgage finance - for example lower interest rates or down payment requirements - will depend on the elasticity of housing supply in various markets. In markets with inelastic supply, even large demand shifts will not increase the homeownership rate, but will instead be reflected entirely in higher prices. These higher prices, in turn, increase the value of the tax deductibility of the mortgage interest and capital gains exclusions, meaning that the preponderance of the benefit from these policies is concentrated in a few areas with high and rising prices and wealthy owners with high marginal tax rates (Gyourko and Sinai, 2004).

Hilber and Turner (2014) provide a detailed study of how the mortgage interest deduction, which has been a common target of tax reformers, affects homeownership rates. In all places, the availability of an income tax deduction for mortgage interest shifts the demand for housing upward, with the size of the shift depending on the owner's marginal tax rate. For owners with higher incomes and marginal tax rates, the value of the tax deduction is large, for those with no income tax liability there is no benefit. In places with elastic supply, these demand shifts induce more building and higher ownership rates. 
But where supply is inelastic, upward shifts in the demand curve are capitalized into higher prices, making the down payment constraint more binding for young borrowers with lower incomes. This increase in cost reduces transitions into ownership for this important group, and Hilber and Turner find that the mortgage interest deduction actually reduces homeownership in inelastically supplied markets. They conclude that because of these offsetting effects the mortgage interest deduction has little effect on overall homeownership.

The experience of other countries is consistent with this conclusion. Canada, the U.K. and Australia, arguably the countries most comparable to the U.S., all do not currently have a mortgage interest tax deduction, but their homeownership rates are very similar to the U.S., in the vicinity of two thirds. ${ }^{15}$ Moreover, the U.K. began phasing out its mortgage interest deduction in 1975 when the value of the deduction as a fraction of interest payments was 38 percent (Gibb and Whitehead, 2007). By 2000, the deduction had been completely eliminated, but the homeownership rate had increased from 50 percent in the 1971 Census to 69 percent in the 2001 Census, ${ }^{16}$ though naturally, a variety of other demographic, economic and policy changes contributed to these outcomes. Andrews and Caldera Sánchez (2011) examine the factors driving the evolution of homeownership rates in 15 OECD countries. While their data does not allow direct estimation of the impact of tax policy on homeownership, they find that more generous mortgage interest tax subsidies are associated with a smaller impact of relaxing down payment requirements on homeownership rates. This is consistent with greater house price capitalization of mortgage-related demand shocks in countries where owned housing receives more favorable tax treatment, thus reducing housing affordability for the marginal buyer and reducing the demand shock's expansionary effect on homeownership.

\footnotetext{
${ }^{15}$ See Bourassa et al (2013) exhibit 2 for a comparison of mortgage interest tax policies and homeownership rates in 24 countries.

${ }^{16}$ U.K. Office of National Statistics; figures are for England and Wales.
} 
As implied by the discussion above, both U.S. and international research have focused on the homeownership effect of public policies, rather than other interesting margins such as the location of new residential units. This is perhaps unsurprising since ownership is an explicit target of many of these policies, and is relatively well-measured. Nonetheless, there is a need for further research intended to improve our understanding of how these various subsidies affect the spatial organization of activities across and within cities, and how they affect the kinds of housing occupied by both owners and renters. Such research would confront many obstacles, including the challenges of accurately measuring housing quality and of identifying the effect of policies that are chosen endogenously by the political system.

One study on the importance of the supply elasticity in determining how credit-induced demand shocks will be transmitted into local market outcomes is Davidoff (2013). Davidoff finds that supply elasticity as conventionally measured does a poor job of explaining the magnitude of the 2000s credit cycle, leaving open the question of why supposedly elastically supplied markets experienced such large booms and busts. One potential answer is found in Genesove and Han's (2013) analysis of the intra-metropolitan effects of the boom-bust cycle of the 2000s. Genesove and Han show that price increases during the boom phase tended to be concentrated in neighborhoods with good access to jobs, which, since such locations are limited, can be thought of as a supply constraint. During the bust, the spatial price gradient flattened, which is consistent with the largest declines in price coming from the most inelastically supplied areas. Much of the work on supply elasticities has been conducted at the metropolitan level, but this approach of studying price and quantity dynamics within cities may hold promise for improving our understanding of the effects of future changes in mortgage finance.

A major lesson of the recent boom and bust in housing markets is that even markets with fairly elastic supply experienced a very significant housing price cycle during the 2000 s. This 
underscores the fact that we have much to learn about how these markets work, especially how mortgage underwriting, the sources of mortgage funding and future price expectations - which will also have an important effect on demand - interact.

Securitization, which is the source of much of the funding for mortgages in the U.S., may itself have spatial consequences. Haughwout et al (2012) demonstrate that during the boom many mortgages which self-reported as owner-occupied loans in fact turned out to be taken out by borrowers with multiple first-lien mortgages, suggesting that they were instead operating as investors. This increase in demand by investors was facilitated by securitization, since downstream investors, unlike originators, do not have access to the borrower's credit report, which is useful for verifying the borrower's intentions. These loans were especially concentrated in boom markets in Arizona, California, Florida and Nevada, and were associated with larger differences between transactions and list prices. When market prices turned around and began to fall, these loans defaulted at very high rates, ultimately leading to spatially concentrated foreclosures.

\section{The distribution of mortgage credit}

One important way that mortgage finance can affect the urban landscape is through its effects on the extent and distribution of homeownership. While the homeownership rate had hovered for decades around 64-65 percent, Figure 1 shows a substantial rise and fall over the most recent housing cycle, notably corresponding to a period of expanding credit followed by credit tightening after 2007. Moreover, underneath the aggregate homeownership rates there is considerable variation across geography and individual household characteristics. At the end of 2013, the aggregate homeownership rate was 65.2 percent, but only 50.2 percent for households 
with below-median income, 45.5 percent for Hispanics, 43.2 percent for blacks and 36.8 percent when the householder is younger than age 35. Some of these differences will reflect preferences, differences in the user cost of owner-occupied housing, as well as the assets, income and credit history required to qualify for loans. However, discrimination in mortgage markets may also affect the ability to secure loans, and the price paid for loans. In this section, we first focus on these issues of discrimination and then examine the distribution of mortgage credit over the life-cycle.

\subsection{Access to mortgage credit}

Figure 6 shows large and persistent differences in homeownership rates by race and ethnicity: the black-white and Hispanic-white gap is never smaller than 25 percentage points. While other factors clearly play a role in explaining these differences, their magnitude naturally prompts the question of whether lenders are unfairly denying mortgage credit to black and Hispanic applicants. Post-Civil Rights era antidiscrimination laws ${ }^{17}$ require lenders to ignore the applicant's race and ethnicity in making mortgage qualification decisions, regardless of whether these characteristics are good proxies for unobservable risk factors that affect the loan's expected return. The laws also prohibit lenders from discriminating on the basis of the racial or ethnic composition of the neighborhood, a practice known as "redlining" because of the red lines that lenders allegedly drew around neighborhoods where they would not make loans.

Earlier research on the role of individual race and ethnicity on mortgage denials was hampered by a lack of adequate data on key underwriting variables used to predict default and the cost of default. In particular, Home Mortgage Disclosure Act (HMDA) data which included many of the necessary variables, lacked information on the applicant's credit history and the property value (thus, LTV could not be calculated). These limitations were addressed in the seminal Boston Fed

\footnotetext{
${ }^{17}$ These include the Fair Housing Act of 1968 and the Equal Credit Opportunity Act of 1974.
} 
study (Munnell et al, 1996) which examined HMDA data from Boston, merged with a comprehensive set of additional variables collected directly from lenders. They estimated a standard loan denial regression, including an indicator for black or Hispanic applicant. Even after extensive controls, the researchers found that loan denials were 8 percentage points higher for blacks and Hispanics. The Boston Fed made the underlying data available and their results have been subject to a great deal of scrutiny. Ross and Yinger (2002) provide a comprehensive assessment of this literature and conclude that the findings are generally robust, providing convincing evidence that Boston lenders discriminated against blacks and Hispanics in $1990 .^{18}$

The research on geographic redlining has been fraught with the same inference problems as studies examining discrimination based on individual race and ethnicity: redlining cannot be isolated without information on individual credit history. ${ }^{19}$ Of the few studies that have adequate controls, there is little or no evidence that lenders systematically denied applications based on neighborhood race and ethnicity. In an extension to the Boston Fed Study, Tootell (1996) estimated loan denial regressions similar to the original study, but replaced the census tract dummy variables with a set of census tract characteristics. He found that a census tract's racial and ethnic composition had no statistically significant effect once individual race and ethnicity are controlled for, and neither did high rates of vacancy and boarded-up property in the tract, nor a large share of low-income residents. Thus, there was clearly individual-based discrimination against non-whites in Boston, but no evidence of redlining. Hunter and Walker (1996) came to a similar conclusion, also using the Boston Fed Study data.

Going beyond the prohibition on redlining, the Community Reinvestment Act of 1977 (CRA) imposes an affirmative obligation on banks (federally insured depository institutions) to help meet the credit needs of their entire service area, including low and moderate income

\footnotetext{
${ }^{18}$ See also Ladd (1998) for a summary.

${ }^{19}$ See Schill and Wachter (1993) for a review of earlier studies.
} 
neighborhoods, which often have disproportionately non-white populations. Bernanke (2007) explains that lending in lower income neighborhoods can be challenging as fewer home sales and more-diverse housing structures make accurate appraisals more difficult, and the short or irregular credit histories of lower-income borrowers makes credit evaluations more costly. The CRA attempts to rectify market failures by inducing banks to invest in the necessary expertise to lend in underserved neighborhoods and reduce the potential first-mover problem where no lender has an incentive to be the first to enter a new market.

Research on the effectiveness of the CRA has tended to find positive effects. For example, Avery et al (2003) find that the census tracts just below the CRA income thresholds had higher homeownership rates, higher growth in owner-occupied units, and lower vacancy rates than those just above; Apgar and Duda (2003) also conclude that the CRA expanded mortgage access for lower-income borrowers, and suggest that its coverage be expanded. However, there are critics that argue that the CRA has been ineffective, not as effective as alternative policies, or that its costs outweigh its benefits. Barr (2005) provides a good overview and critique of these criticisms, ultimately concluding that the CRA is a reasonably effective policy to overcome market failures and discrimination.

\subsection{The distribution of high cost lending}

Mortgage lending practices rapidly changed in the early 2000s with a large expansion of credit, especially in the subprime market, as shown in Figure 7. New mortgage products requiring lower down payments, lower credit scores and possibly little or no documentation of assets and income became much more widely available, fueled by the increased securitization of subprime mortgages. But of course, these products typically came at additional cost to the borrower. Moreover, these additional costs were potentially unclear to borrowers because the loans often had 
relatively complex features such as initial "teaser" rates that would be followed by a large payment jump even if market interest rates remained constant. ${ }^{20}$ This led to a heightened concern that low income and non-white individuals and neighborhoods were disproportionately receiving higher cost loans, particularly those with large expected rate resets that borrowers could not possibly afford. Lenders and mortgage brokers were accused of steering borrowers to inappropriately structured mortgages with high costs. On the borrower end, the concern was not only about adequate disclosure, but also that individuals with limited financial literacy may not understand how the teasers work and underestimate how much their rate could increase, or they may overestimate their ability to pay the higher reset rate or simply not consider it important due to myopia or hyperbolic discounting.

Numerous studies have documented patterns of high cost or subprime lending by income, race and ethnicity. For example, Mayer and Pence (2009) examine several data sources and find that in 2005, subprime mortgages were increasingly concentrated in zip codes with higher proportions of black and Hispanic residents, even after controlling for zip code income and credit scores. As measured by the fraction of black residents, the 90 th percentile zip code had 42 percent more subprime loans than the corresponding median zip code, and as measured by the fraction of Hispanics, the 90th percentile zip code had 33 percent more subprime originations. They also suggest that subprime loans are more prevalent in locations where credit might be more difficult to obtain, such as zip codes with mid-level credit scores or counties with higher unemployment rates.

Figure 8 provides an illustration of the geographic concentration of subprime lending in predominantly black and Hispanic neighborhoods in New York City. The shading shows the share of black or Hispanic residents in each census tract, while each dot represents the census tract location of one higher cost loan originated in 2006. As defined by HMDA, a higher cost loan is one

${ }^{20}$ Mayer et al (2009) provide a good description of the structure and risk characteristics of subprime and near-prime mortgages. 
where the APR is greater than 3 percentage points above a Treasury of comparable yield - this is a commonly used measure of subprime mortgage.

While not considered part of the subprime market, Pinto (2012) argues that many FHA fixed-rate mortgages originated during this period displayed characteristics that were typical of subprime loans including low credit scores, low down payments and high debt-to-income ratios, particularly those originated in zip codes where median family income was below the median family income for the MSA. Like their subprime counterparts, these loans experienced very high default rates, resulting in disproportionately high foreclosure rates in disadvantaged neighborhoods.

To the extent that blacks and Hispanics and households with low income are more likely to be credit constrained and less able to qualify for conventional loans, the expansion of subprime high cost lending could be welfare improving as it enhances the ability to own a home or to withdraw home equity. However, if subprime loans were substitutes for cheaper conventional loans, then the outcome is clearly of concern for equal access to credit reasons, even without considering the subsequent foreclosure crisis and its associated negative spillovers. Disentangling these two effects is a challenge because it is impossible to construct precisely the set of mortgages that a borrower could have qualified for. Furthermore, mortgages are differentiated along many dimensions. Loans with different terms, amortization and rate schedules, and prepayment penalties, for example, will have different values for borrowers depending on their expected housing duration and expectations about housing appreciation and their own future income trajectory. Without information on these individual factors, it can be difficult to conclude that one loan is necessarily expected to be more costly than another for a given borrower, even if the whole choice set is observed.

Many studies examine mortgage pricing using HMDA's annual percentage rate (APR) measure which amortizes interest payments and up front fees over the full maturity of the loan, and reports the spread over a Treasury security of comparable maturity when this spread is at least 3 
percentage points. This collapsing of price into a single left-censored measure presents several problems that should be borne in mind in considering the literature. First, for a given combination of up front fees and rising rate schedule, a borrower with a shorter expected housing duration will have lower costs, despite the same measured APR. Second, borrowers rarely hold a mortgage to its maturity. Two mortgages can have the same APR and have quite different expected costs assuming an expected duration shorter than maturity. To the extent that non-whites are more likely to be targeted for high up front fees, HMDA's APR measure would not be able to uncover this form of discrimination and would underestimate disparities. Third, leaving aside any up front costs, the APR concept may also be problematic with hybrid adjustable rate mortgages (ARMs) where a substantial portion of borrowers prepay at the first reset (many loans had prepayment penalties that expired at this point). A lender can thus tweak the rate adjustment formula to achieve any APR without significantly impacting the likely payment stream generated from the mortgage. Finally, the leftcensoring may prevent discrimination of borrowers with better credit from being uncovered as they are less likely to have rates above the left-censoring threshold.

Analyses of the post-2000 data that rely solely on HMDA data (for example, Avery et al, 2005) tend to find substantial adverse pricing effects for blacks and Hispanics, but they are severely hampered by a limited set of explanatory variables, including no information on credit scores or LTV. Bocian et al (2008) overcome this problem by merging HMDA with a large proprietary subprime loan dataset containing much more information on borrower risk attributes. They run their analysis separately for subprime 30-year FRMs and the most popular ARM, the 2/28 (a hybrid ARM with an initial 2-year teaser rate followed by rate resets at 6 month intervals for the remaining 28 years). They further segment these two groups by whether they had prepayment penalties and by purchase vs. refinance loans. In general, their analyses show that among home purchase loans with prepayment penalties, blacks and Hispanic borrowers were significantly more likely to receive APRs 
that exceeded HMDA's reporting threshold of 3 percentage points above Treasuries, and that these disparities were greater for FRMs compared with 2/28 ARMs. However, there was little significant difference for either FRMs or ARMs without prepayment penalties or for refinance loans. Bocian et al do not estimate the amount by which race and ethnicity increases the APR, and imply that the left censoring makes it impossible to do so. Their focus on the subprime market leaves open the broader question of whether some borrowers were steered into subprime mortgages when they could have qualified for cheaper conventional loans.

Courchane (2007) is able to incorporate both prime and subprime loans by using a (nonrepresentative) sample from 22 lenders. This proprietary data is not constrained by HMDA's left censoring of the APR and contains the critical underwriting variables of debt-to-income, credit score and LTV. Courchane examines 2004-2005 originations to estimate the probability of taking out a subprime mortgage and the determinants of APR conditional on receiving a subprime or prime mortgage using an endogenous switching framework. The results suggest that virtually all of the race-ethnicity difference in use of the subprime market and the vast majority of the black-white and Hispanic-white APR gap can be explained by observables that are appropriately used in underwriting and pricing. The remaining unexplained gap in APR is economically small ${ }^{21}$ and the analyses suggest that they primarily come from within the prime or subprime market, rather than from selection across the two markets.

More recently, Bayer et al (2014) link 2004 to 2008 HMDA data to credit reports and to public property and mortgage deeds in seven cities. Their merged data allow them to control for a rich set of risk attributes including the presence of a junior lien, and to capture both the prime and subprime markets. However, they remain hampered by HMDA's left censored APR as their measure of high cost pricing and only model the likelihood that a borrower will receive a loan with

${ }^{21} 0.09$ to 0.10 percentage points higher for blacks and 0.08 to 0.11 higher for Hispanics, compared with white borrowers. 
an APR that exceeds HMDA's threshold. Bayer et al find significant and substantial unexplained disparities, with black, Hispanic and older borrowers more likely receive high APR loans. In particular, they find the largest difference exists for black homebuyers across the credit score spectrum, and especially in counties where recent black homebuyers are less likely to have some college education. For Hispanic borrowers and older borrowers, the difference is primarily concentrated among borrowers with low credit scores or high LTVs. Bayer et al also conclude that substantial amounts of the estimated disparities are due to sorting across lenders as the disparities are substantially reduced when lender fixed effects are included in the models.

Another strategy that has been taken by several studies is to examine some of the components of APR, rather than HMDA's APR itself. This method necessarily has to side step the issue of selection and steering by focusing more narrowly on specific products to examine whether lenders price a given product differently for different borrowers, but is able to generate an estimate of the size of any pricing disparity. Haughwout et al (2009) use data from the servicing records of securitized non-prime mortgages merged with HMDA and focus on 2/28 ARMs. In contrast to much of the previous literature, they find that after controls for risk characteristics and neighborhood composition, black and Hispanic borrowers get slightly more favorable terms, although the sizes of these effects are economically tiny. ${ }^{22}$ On the other hand, Asian borrowers paid slightly higher initial rates and reset margins. They also found that loans were cheaper in zip codes with a higher percentage of Asian, black, and Hispanic residents, as well as in counties with higher unemployment rates, consistent with the higher concentrations of subprime lending in these locations found by Mayer and Pence (2009). One drawback of their data is that it does not include information on any points or fees that the borrower may have paid at origination, so it remains

\footnotetext{
${ }^{22}$ Initial mortgage rates are about 0.025 percentage points lower for blacks and Hispanics than the average of 7.3 percent, and reset margins are 0.017 to 0.05 percentage points lower than the average of 5.9 percent.
} 
possible that the estimated lower interest rates and reset margins are due to higher fees having been paid, or that in fact, higher fees were disproportionately charged to non-white borrowers, even after accounting for slightly lower rates and margins. And of course, these analyses leave open the broader question of selection into products.

Ghent et al (2014) use similar data to focus on securitized non-prime originations in California and Florida in 2005. They examine the seven most popular non-prime mortgage products and a category for the remainder, but like Haughwout et al (2009), they conduct their analyses for each product separately and do not consider steering or selection either among the various products or with the prime market, and they cannot examine up front points and fees. Their empirical strategy differs from Haughwout et al in that they also control for possible differences in default and prepayment probabilities in their pricing models. Ghent et al's findings suggest adverse pricing for black and Hispanic borrowers, and in neighborhoods with a higher share of non-white residents, but the magnitude of these effects is relatively small. ${ }^{23}$ Their results also indicate that these disparities cannot be entirely explained by the (significant) effect of individual or neighborhood race and ethnicity on the two year probabilities of default or prepayment. It is important to emphasize that this form of statistical discrimination is illegal, but nonetheless, the analysis is useful for understanding the source of any disparities. These findings suggest that the disparities go beyond this particular illegal form of statistical discrimination.

Interestingly, Ghent et al find virtually no differential pricing for refinance mortgages. Because refinance borrowers already have a mortgage and are thus more knowledgeable with respect to mortgage markets, the authors argue that this finding suggests that the adverse pricing is "not due to discrimination on the part of lenders per se." Rather, they argue it is due to non-white home

${ }^{23}$ For example, for the 30-year ARM (the most product), black and Hispanic borrowers faced interest rates that were respectively 0.12 and 0.29 percentage points higher than other borrowers, and a 10-percentage-point increase in the neighborhood share of blacks or Hispanics is associated with, at worst, a 0.014 percentage point increase in rates. 
buyers searching less intensively or effectively for the best possible rate compared with similar white home buyers, perhaps because non-whites are less likely to benefit from community or intergenerational transfers of mortgage market knowledge. It is worth noting though that the more knowledgeable refinance borrowers are also less likely to be susceptible to aggressive marketing tactics and steering, and thus the lack of an adverse pricing effect for refinance borrowers could simply be because they are more able to resist the possibly discriminatory actions of mortgage brokers or lenders. Finally, if there are characteristics of the borrowers that are unobserved to the econometrician but observable to loan underwriters, then borrowers seeking to refinance a mortgage are a selected sample relative to borrowers seeking to purchase their first home. Thus, pricing differentials observed for purchase mortgages could reflect sample selection.

Some research has focused specifically on the role of mortgage brokers in determining the price paid by borrowers. Brokers were able to receive compensation directly in the form of cash from the borrower (points), as well as indirectly via a commission from the lender to the broker (the yield spread premium), which results in a higher interest rate for the borrower. Woodward and Hall (2012) examine the sum of these two sources of broker commissions using data on a sample of FHA fixed-rate home purchase loans originated in 2001. In their data, black and Latino borrowers paid higher total broker commissions than white borrowers with similar loan amounts and credit scores, while borrowers from census tracts with higher educational attainment paid lower commissions than similar borrowers elsewhere. Their results suggest that shopping from too few brokers resulted in borrowers sacrificing at least $\$ 1,000$, and that borrowers who compensated brokers with both cash and a lender commission paid twice as much as similar borrowers who paid no cash. They argue that the primary reason for this seemingly irrational behavior is borrower confusion - borrowers may misunderstand the broker's role to be helping them search for the 'best' mortgage, and they may think that points and the loan's interest rate are independent rather than a 
tradeoff. Woodward and Hall's conclusion is consistent with Courchane et al (2004) who analyzed data from a survey of prime and subprime borrowers in 2001. They found that borrowers who engaged in less search activity and had less mortgage market knowledge were more likely to get a subprime loan, even after controlling for underwriting variables such as LTV and credit score.

One conclusion from this strand of literature is that borrowers would benefit substantially by more search activity, including shopping from additional brokers. But Hanson et al (2013) also provide some evidence that mortgage brokers treat borrowers differently depending on their race and their credit score. They conducted a matched-pair field experiment in which brokers were emailed requests for assistance with obtaining a mortgage from fictitious borrowers who varied by credit score and by race. ${ }^{24}$ Hanson et al find a small but significant difference in the likelihood of responding to black clients compared with white clients. ${ }^{25}$ Larger response differences were found by credit score, and these exacerbated differences in the differential response by race. Furthermore, even among brokers that responded to both races, the content of the replies tended to offer more details and used more friendly language (as judged by an external review panel), although overt discriminatory actions such as offering less favorable terms or steering into a product was rare.

Any differential treatment by mortgage brokers should be considered in combination with the behavior of other actors in the residential real estate market. The Department of Housing and Urban Development (HUD) has conducted a series of paired-testing studies beginning in 1977 to monitor discrimination by real estate agents. In the most recent, Turner et al (2013) find that black and Asian homebuyers are told about and shown significantly fewer available homes than equally

\footnotetext{
${ }^{24}$ Race was signaled through the use of names with a high likelihood of association with one race. See Ross et al (2008) for an earlier example of matched-pair testing in the mortgage application process using live testers in 2000, which found that non-whites received less information and assistance than comparable whites in Chicago, but not in Los Angeles.

${ }^{25}$ On net, 1.9 percent of brokers do not respond to inquiries from black clients while responding to white clients.
} 
qualified whites. ${ }^{26}$ This differential treatment by agents not only constrains choices; it raises the cost of housing search and exacerbates any differential treatment or differences in search costs experienced in the mortgage application process.

\subsection{Mortgage finance over the lifecycle}

The simple model of the demand for owner-occupied housing presented earlier in this chapter focused on the user cost of housing. Standard economic theory posits that in the absence of liquidity constraints, households choose to consume goods (including housing) to maximize their utility in each period subject to their lifetime budget constraint. Preferences and permanent income will thus determine the amount of housing that a household demands, and the user cost of housing will determine whether the household rents or owns. But of course liquidity constraints are real and important, both in terms of access to credit and the ability to liquidate a large lumpy asset. The structure of mortgage finance affects the tenure decision and the amount of housing consumed over the lifecycle, with implications for the urban landscape.

There is a clear pattern of increasing homeownership rates as households age that is mirrored by declines in mortgage holding, as shown in Figure 9. Below, we discuss the implications of mortgage finance for periods in the lifecycle where current income is least likely to equal permanent income. At younger ages, borrowing constraints are most important, while at older ages, the ability to draw down housing equity is the biggest concern.

\subsubsection{Transitions to homeownership}

\footnotetext{
${ }^{26}$ Black and Asian homebuyers who contact agents about recently advertised homes for sale learn about 17.0 and 15.5 percent fewer available homes respectively, and are shown 17.7 and 18.8 percent fewer homes respectively. No significant difference was found for Hispanic homebuyers.
} 
Even in the absence of liquidity constraints, we would expect younger households to have lower rates of homeownership for several reasons. First, households early in their career will tend to have lower marginal tax rates, which increases the user cost of owner-occupied housing, all else equal. Second, younger households, particularly those who are single and childless, have more flexibility in moving for labor market opportunities, and possibly a higher propensity to search for a residential location with their preferred mix of services and amenities. This preference for greater mobility means that they are less willing to incur the substantial transactions costs associated with buying and selling a home, compared with moving between rental homes. Third, in many parts of the U.S., owned homes and rental homes are fundamentally different in terms of their physical attributes, surrounding neighborhood and access to local public goods. Rental options for detached single-family homes with private outdoor space and amenities such as high performing public schools and low crime rates are often quite limited in some jurisdictions, partly due to zoning regulations. These provide a motive for owning versus renting, beyond user cost considerations, that will be less important for younger households given their preferences.

That said, credit constraints arising from the structure of mortgage finance undoubtedly constrain some households in the timing of making a transition from rental to owner-occupied housing. To qualify for a mortgage, borrowers generally need to demonstrate a credit history that signals a willingness to repay debts and a steady income stream that signals the ability to pay; households early in their careers are less likely to possess either. Younger households are also more likely to have outstanding student loans, reducing the ability to borrow further for housing purchases. But it is arguably the down payment requirement that poses the greatest hurdle for renters who aspire to be owners. 
Surveys of renters have consistently reported saving for a down payment plus closing costs to be a major obstacle to homeownership. ${ }^{27}$ The Census Bureau's Housing Affordability Index uses data from the Survey of Income and Program Participation (SIPP) to capture the ability of households to purchase a modestly priced home in their area, based on their income, assets and debts, and the assumption of a 30-year conventional mortgage with a 5 percent down payment (see Wilson and Callis, 2013). ${ }^{28}$ The SIPP lacks credit history information so this affordability measure cannot capture borrowing constraints arising from poor credit history. In 2009, the most recent year available, 93 percent of renters could not afford to buy a modestly priced home, and among them, one in four had sufficient income to qualify for a mortgage but not enough cash for a down payment. $^{29}$

For many young households, saving for a down payment will likely involve less consumption of both housing and other goods than would have occurred otherwise. Engelhardt (1994) uses the Panel Study of Income Dynamics (PSID) to estimate the sacrifice associated with saving for a down payment and finds that real food consumption growth is 10 percent lower during periods when a household is saving for a first home, compared to after the home purchase.

There is also good evidence that transfers from family members alleviate down payment constraints and accelerate the transition to homeownership. For example, Cox and Jappelli (1990) find that intergenerational transfers are intentionally directed towards younger generations facing liquidity constraints. Engelhardt and Mayer (1998) find that transfers from parents lead to earlier purchases of more expensive homes, and that the prevalence of family help is substantial: 22 percent

\footnotetext{
${ }^{27}$ National Association of Realtors (2013).

${ }^{28}$ A "modestly priced home" is defined as the 25 th percentile of owner-occupied homes in the household's metropolitan area, or within the household's state.

${ }^{29}$ An additional 74 percent had both insufficient income and insufficient cash, and 2 percent had insufficient income only.
} 
of first-time homebuyers receive a down payment gift and the average gift is more than half the down payment.

These intergenerational transfers can serve to perpetuate wealth concentration and homeownership disparities across income, race and ethnicity. ${ }^{30}$ Homeownership is widely recognized as a tool for wealth building among lower income households because the monthly payment on an amortizing mortgage serves as a form of forced saving. Moreover, the effect of leverage means that a mortgage borrower gets the benefit of the entire increase in the home's value despite only putting down a fractional equity stake (the down payment). Herbert et al (2014) argue that these wealth accumulation benefits of homeownership for lower income households remain intact despite the recent housing boom and bust. Down payment constraints may thus exacerbate wealth concentration by postponing wealth building for households that do not have access to family gifts. The problem is even worse when we consider the possibility that the accumulated home equity is further used in wealth creation, as capital for small businesses or to finance human capital accumulation of younger generations. ${ }^{31}$

Another way of viewing the borrowing constraint is in terms of the all-or-nothing nature of the homeownership decision. Housing costs are a large share of most families' budgets, and at present, there is limited scope for dividing housing into part-rent and part-own. Typically, mortgages cover the entire house and thus down payment requirements are substantial relative to incomes. However, housing tenure options that fall in between rental housing and traditional homeownership do exist and are often collectively known as shared equity homeownership. In this alternate form of ownership, the resident consumes the entirety of housing services, but is a partial owner of the underlying housing asset and takes a fraction of any appreciation or depreciation.

${ }^{30}$ Hilber and Liu (2008) provide evidence that parental transfers explain part of the black-white gap in homeownership.

${ }^{31}$ Lovenheim (2011) finds that housing wealth has a substantial positive effect on college enrollment, particularly for low and middle income families. 
Existing shared equity programs generally rely on an institution to provide the remaining share of equity. Lubell (2014) gives an overview and assessment of models that focus on lower income households, typically with a local government or a not-for-profit institution providing the shared equity. Some universities operate shared equity housing programs for their employees in the form of shared appreciation mortgages. ${ }^{32}$ The structure of these mortgages vary, but they generally offer the borrower reduced or deferred interest payments in exchange for a share of the appreciation.

In contrast to these existing models, Caplin et al (1997a) have devised a system of shared ownership that relies on an investor market for the non-resident equity share. In these "housing partnerships", the homeowner and resident (the managing partner) and a private investor (the limited partner) share the purchase of the home and the subsequent proceeds from its sale. The amount of borrowing required by the homeowner is scaled back proportionate to their share of the partnership and thus the mortgage (both down payment and monthly payments) becomes much more affordable. Caplin et al envision a secondary market for limited partnerships, analogous to those for regular mortgages.

\subsubsection{Mortgage finance at older ages}

It is well known that in coming decades, the U.S. population is likely to age considerably due to increases in life expectancy and the aging of the baby boom generation. ${ }^{33}$ This aging makes it particularly important to consider the impact of mortgage finance on older adults, as it may shape their choice of location, and consequently the kinds of community support and services that should be provided. There is a widespread belief among policy makers and advocates that aging in place -

\footnotetext{
${ }^{32}$ For example, Harvard, NYU and Stanford offer these programs to some employees.

${ }^{33}$ According to projections, the population aged 65 and above is expected to more than double between 2012 and 2060. U.S. Census Bureau: 2012 National Population Projections.
} 
living in one's home for as long as possible - is a desirable outcome that benefits older adults and their communities, and that yields individual and public sector cost savings. ${ }^{34}$ Appropriate mortgage finance instruments and institutions may have a role to play in increasing older households' ability to age in place.

At older ages, an important issue for homeowners is how they can draw down their accumulated home equity or convert it into a stream of income for consumption during retirement. As previously shown in Figure 9, homeownership rates increase with age, reaching over 80 percent for householders aged 65 and above, while the share of homeowners with a mortgage is monotonically declining with age. Moreover, home equity is the primary component of nonpension wealth for most seniors. ${ }^{35}$ But homes are lumpy and illiquid assets, which complicates matters. Homeowners who want to reduce their housing equity have several options. Selling the home and moving to another of lesser value or to rental housing is an obvious solution to extracting home equity, but it requires the homeowner to move. This likely involves substantial psychic costs: a widely reported 2010 AARP survey found that three quarters of respondents aged 50 or above strongly agreed with the statement "what I'd really like to do is stay in my current residence for as long as possible." 36

Allowing the home to depreciate by reducing home maintenance is another method of consuming home equity. But, unlike the temporary deferral of home maintenance for consumption smoothing purposes, a persistent reduction is unlikely to be optimal. Davidoff (2006), using data from the AHS, finds that homeowners aged 75 or more spend significantly less on routine maintenance and have a much lower propensity to undertake major repairs, resulting in reduced

\footnotetext{
${ }^{34}$ See HUD (2013) for a summary of evidence.

${ }^{35}$ Poterba et al (2011).

${ }^{36}$ Keenan (2010).
} 
housing appreciation that greatly exceeds the savings from under-maintenance. This difference could be interpreted as the cost associated with extracting home equity using this approach.

Taking on greater housing debt using additional mortgages, HELOCs, or via a cash-out refinance would be the straightforward way to use mortgage finance to reduce home equity without having to move. But, for retired homeowners, additional monthly payments may pose a qualification constraint for borrowing, ${ }^{37}$ and uncertainty regarding medical costs at older ages may lessen the attractiveness of higher monthly obligations during retirement. HELOCs have the additional problem of balloon payments that the borrower may not be able to refinance when the line of credit ends.

Reverse mortgages have the advantage of allowing homeowners to withdraw equity without having to make monthly mortgage payments, and the loan has to be repaid only when the borrower moves, sells the home, or dies. The FHA-insured Home Equity Conversion Mortgage (HECM) currently accounts for nearly all reverse mortgages in the U.S. HECMs allow borrowers aged 62 and above to access their home equity as a line of credit, as a term or lifetime annuity, as a lump sum, or in some combination of these options. These loans are non-recourse to the borrower and any heirs. The sizeable insurance premiums are intended to cover the risk of negative equity at termination, either because the borrower lived longer than actuarial expectations or because home prices declined.

Given their advantages and the potentially large numbers of people that could qualify and benefit from them, a long-standing puzzle had been why reverse mortgages remained relatively unpopular. There is a substantial literature on whether the elderly want to, or should, consume their home equity. ${ }^{38}$ Besides pecuniary attachment to a home that may lead to a preference for leaving

\footnotetext{
${ }^{37}$ In particular, the declining popularity of defined benefit pensions coupled with low rates of annuitization may have led to less pension income, as opposed to wealth, in retirement.

${ }^{38}$ See Poterba et al (2011) for a summary.
} 
housing, as opposed to other assets, as a bequest, and the favorable treatment of home equity by some social programs ${ }^{39}$, the literature has emphasized the usefulness of a non-annuitized stock of wealth, such as housing, as a source of precautionary saving. ${ }^{40}$ But while older households may be reluctant to draw down home equity because of the insurance it provides, when adverse events do in fact occur, it is important for them to have a vehicle by which they can access that equity.

Since the mid-2000s, demand for reverse mortgages has increased dramatically, though it has subsequently fallen and, while originations are still much higher than in 2000 , they remain low. Davidoff (2013) argues that, under a set of reasonable assumptions, HECMs historically offered borrowers favorable pricing and thus weak demand cannot be attributed to their high cost. Several studies indicate that the growth in demand in the 2000s mirrored the credit expansion for other forms of housing debt in that it was at least partly driven by house price growth. Shan (2011) provides a descriptive analysis of trends from 2003 to 2007 and concludes that house price increases account for about one-third of the growth in the reverse mortgage market. More recently, Haurin et al (2014) examine state-level variations in the take-up rate of HECMs from 2000 to 2011 and find that states where real house prices were more volatile relative to historic trends had substantially higher take up rates. They argue that this behavior is consistent with homeowners anticipating future reductions in house prices and locking in their equity gains.

The Consumer Financial Protection Bureau (2012) reports that the age distribution of HECM borrowers has become younger, and that borrowers have more debt and are increasingly taking the full amount for which they qualify as a lump sum upfront payment (73 percent of HECM borrowers in 2011). They suggest that borrowers are increasingly using HECMs to refinance traditional mortgages without having to make monthly payments; essentially, they are using their

\footnotetext{
${ }^{39}$ Provisions vary by state, but the primary residence is often excluded in asset tests for Medicaid and Supplemental Security Income eligibility.

${ }^{40}$ For example, Davidoff (2010) argues that households tap into their housing equity when they need long-term care and that this explains the low demand for long-term care insurance.
} 
existing home equity to service the debt. This puts them at greater risk for mobility lock-in due to negative equity, compared to a traditional mortgage product, and of course they now have less precautionary saving for unexpected expenses or to finance a future move. While there is no labor market impact from lock-in for retired homeowners, the death of a spouse or an adverse health event that limits daily activities may make moving to another residence a preferred strategy. But, for individual borrowers, these risks need to be balanced against the benefit of additional cash flow and the ability to remain in their home indefinitely. While there is some limited survey evidence on how and why borrowers use reverse mortgages, this is an area where information and research is currently lacking.

There is no research that we are aware of on maintenance and home investment by reverse mortgage borrowers. Under the HECM terms, borrowers are required to keep the home in good repair. ${ }^{41}$ The findings of Eriksen et al (2013) suggest that older homeowners should be investing more in home maintenance and improvements as they age in order to prevent accidents that precipitate large medical costs. ${ }^{42}$ Since reverse mortgages can be used to help fund home improvements, they have the potential to help adapt the existing housing stock to an increasingly aged population.

The HECM insurance fund has sustained heavy losses since the housing market passed its peak, because of negative equity at loan termination. ${ }^{43}$ Moreover, by February 2012, nearly 10 percent of HECMs were in default for failure to pay property taxes or homeowner's insurance, placing many homeowners at risk of foreclosure. The two largest originators (with 36 percent

\footnotetext{
${ }^{41}$ If the home falls into bad repair and the borrower does not make repairs when requested, the lender has the right to foreclose.

${ }^{42}$ Their estimates suggest that each dollar spent on home safety and accessibility features is associated with a 93-cent reduction in medical costs from fewer non-fatal falls, and that for those 75 and older, the reduction in medical costs far exceed a dollar-for-dollar return. These estimates only count medical and not any psychic costs or the value of any formal or informal post-acute care. ${ }^{43}$ Integrated Financial Engineering (2012)
} 
market share between them) exited in 2011, with one of them citing reputational concerns from foreclosing on seniors (Consumer Financial Protection Bureau, 2012). As a response to these problems, HUD has recently limited the ability to take large up-front payments, and has introduced new underwriting criteria based on income and creditworthiness to assess HECM borrowers' ability to meet tax and insurance obligations. To date, research on the determinants of reverse mortgage default has been hampered by the lack of appropriate data as risk characteristics such as credit score, debt and income were not used in the loan approval process. ${ }^{44}$

Problems with the HECM program may reflect the historic up-and-down swing that the housing market has experienced over the last decade and not its long-run sustainability. However, that sustainability, or lack of sustainability, may be an important factor in shaping communities in the future. With HECM's dominant position in the reverse mortgage market, its continued functioning may be an important factor affecting homeowners' ability to draw on home equity while aging in place.

\section{Negative Equity}

The significant house price declines during the housing bust created an unprecedented level of negative equity. Figure 10 shows the shares of mortgages that were in negative equity over time. CoreLogic reported that in the fourth quarter of 2009 a total of 11.3 million mortgages or 24 percent of borrowers were in negative equity. Data from the American Community Survey (ACS) indicates that roughly two-thirds of homeowners have a mortgage. This implies that at the end of 2009 nearly

${ }^{44}$ Preliminary findings from Moulton et al (2014) suggest that credit score, prior delinquencies, and large up front payments are important predictors. Davidoff (2014) argues that selection on home price movements and the demographics of HECM borrowers explains roughly half of the poor performance in HECM loans. 
16 percent of homeowners were in negative equity. Since 2009 , the combination of house price increases in most markets, debt amortization and foreclosures has slowly reduced the extent of negative equity. CoreLogic reported for the third quarter of 2013 that the number of mortgages in negative equity was down to 6.4 million.

Given the significant magnitude of negative equity that was created as a result of the housing bust, it is important to explore possible consequences of this negative equity for local housing markets. Three important areas of inquiry are implications for strategic default, the turnover rate of the housing stock and the degree to which homes in negative equity are being adequately maintained. Strategic default clearly affects foreclosure rates, a topic we discuss later in this chapter. The turnover rate is important in that it determines the degree to which households are able to sort across houses over time. Turnover also helps to promote price discovery. Furthermore, there tends to be significant expenditures made by households when they move into a home. ${ }^{45}$ In addition, one source of revenue to local governments is transfer fees levied on property sales. ${ }^{46}$ The turnover rate, therefore, can have implications for local economic activity beyond housing. As noted earlier, housing investment expenditures represent an important offset to the physical depreciation rate for the local housing stock and are an additional source of local economic activity.

\subsection{Negative equity and strategic default}

When a household in negative equity can afford to continue making the mortgage payments, they still have an option to default on the mortgage, in which case the house is sold in foreclosure. We will label this as "strategic default." If the mortgage is non-recourse, the cost to the household from making this choice is that their credit is severely damaged for several years, restricting their

${ }^{45}$ For example, Haughwout et al (2013) report that on average households spend \$2,500 (in 2012 dollars) in additional home maintenance and improvements during the first year in a house.

${ }^{46}$ See Lutz et al (2011) for a detailed analysis of the impact of the housing boom and bust on state and local government revenues. 
access to and raising the cost of future borrowing. As we will make clear, to ascribe the house sale to the negative equity it is important to restrict our attention to cases of strategic default. This is in contrast to a traditional default that results from the combination of an adverse income shock and negative equity. This type of default is driven by the adverse income shock which requires that the house is sold, whereas the negative equity simply determines how the house is sold - by the owner or by the bank.

Estimating the relative importance of strategic default has been challenged by the lack of data on individual borrower income and mortgage payments. Consequently, early attempts at measuring strategic default used methods of indirect inference. For example, Experian OliverWyman (2009) use credit records to identify potential strategic defaulters. They stipulate that strategic defaulters must meet two conditions: the borrower goes straight from current to default on their mortgage, and the borrower continues to pay their other credit obligations for 6 months after going 60-days delinquent on the mortgage. Using these criteria, they find that 18 percent of defaults appear to be strategic. A weakness of this approach is that it does not control for two key factors negative equity and absence of adverse income shocks.

Bradley et al (2012) are able to remedy this deficiency. The authors use monthly mortgage servicing data that is merged to credit and payroll data. Their sample is selected towards borrowers who work in large firms that are more likely to outsource their employment/income verification to a credit bureau. Using the Experian Oliver-Wyman criteria they identify 21 percent of defaults as strategic. Adding in the negative equity and the absence of an adverse income shock reduces this to 14 percent. The authors report that the relative prevalence of strategic default is increasing in a borrower's credit score as well as current LTV. Their results suggest that despite the severe magnitude of negative equity created during the housing bust only a minority of defaults appears to be strategic in nature. 


\subsection{Negative Equity and Housing Turnover}

How might negative equity impact the turnover rate of housing? For this discussion, we focus on the turnover of owner-occupied (as opposed to rental) housing. In this context, a house turns over when it is sold and ownership is transferred. Prior to the housing bust, the incidence of negative equity was relatively low. As a consequence, the early literature focused on house price declines that reduced the borrower's equity, but not to the degree that the household was in negative equity. Attention was focused on situations where an owner is both selling a home and buying a subsequent home. Stein (1995) argued that equity reductions resulting from house price declines can limit mobility since the borrower will not have sufficient remaining equity to fund the down payment on a subsequent purchase of a similar or higher priced home. That is, to move to another ownership situation the borrower would either have to make up part of the new down payment from other financial assets or move to a less expensive home. ${ }^{47}$ In either case, price declines create a financial friction to selling.

The financial friction to selling created by declining house prices is magnified if these price declines are sufficient to place the household in negative equity. To sell the home, a household in negative equity must be able to pay off the balance of the mortgage. ${ }^{48}$ This requires the household to have the financial assets to be able to make up the deficiency between the balance on the mortgage and the proceeds from selling the home less the transactions costs, creating a financial friction to

\footnotetext{
${ }^{47}$ Additionally, a household could move from ownership to rental. Here the friction is the ability to find a similar home and/or location in the rental market. Default would not be a rational outcome so long as the household has enough remaining equity to cover the transactions costs from selling the home.

${ }^{48}$ The lender could negotiate a short-sale agreement with the household where the household sells the home and the lender agrees to accept less than the outstanding balance on the mortgage. Shortsales represented only 6.6 percent of total home forfeitures in the first quarter of 2008 and rose to 25.2 percent of home forfeitures by the fourth quarter of 2013. See OCC Mortgage Metrics Report, various issues.
} 
selling regardless of the household's subsequent tenure decision. Furthermore, to both sell and buy a subsequent home the household faces an even higher hurdle in that it must pay off the deficiency as well as completely fund a new down payment.

The overall predicted impact of negative equity on owner-occupied housing turnover depends on the relative importance of strategic default. If strategic default is uncommon, then bolding constant the borrower's income we would expect that negative equity would reduce housing turnover. That is, the financial friction to selling a home without a default would outweigh the strategic default effect on overall housing turnover. However, if strategic default accounts for a significant amount of overall default, then negative equity could increase housing turnover. ${ }^{49}$ As discussed above, estimates suggest that most defaults are not strategic. A consequence is that a vast majority of housing turnover related to mortgage default is likely the result of adverse income shocks and not directly due to negative equity.

Empirical work on the relationship between negative equity and mobility divide importantly along the definition of what constitutes a "move." We will focus our discussion on studies using household level data. ${ }^{50}$ Chan (2001), Engelhardt (2003), Ferreira et al (2010, 2011) and Andersson and Mayock (2013) focus on moves that involve a transfer of ownership. In contrast, SchulhoferWohl (2011), Bucks and Bricker (2013) and Coulson and Grieco (2013) focus on changes of household residence, regardless of whether the ownership of the property has changed hands. The distinction is important since not all changes of household residence involve a change in ownership, whereas changes in ownership nearly always involve as well a change in household residence.

\footnotetext{
${ }^{49}$ If the incidence of strategic default is higher the larger the degree of the negative equity, then negative equity may have a non-linear impact on housing turnover. Low levels of negative equity may reduce turnover while high levels of negative may increase turnover. The possibility of a Ushape relationship between negative equity and housing turnover is discussed in Andersson and Mayock (2013).

${ }^{50}$ For examples of aggregate studies see Donovan and Schnure (2011) and Nenov (2010).
} 
The appropriate definition of a move depends on the specific questions being investigated. For studying the impact of negative equity on local housing markets, we argue that housing turnover is the relevant concept - that is, moves that involve the sale of the home. In contrast, for studying the impact of negative equity on labor markets, household turnover is the more relevant concept. Job mobility is an important element of the functioning of a labor market. Job changes can occur with or without housing turnover. Given our focus on local housing markets, we will focus on moves that entail the sale of a home..$^{51}$

For moves that involve the transfer of ownership in the home, the evidence supports the hypothesis that negative equity limits mobility. However, no study provides a clean test either because changes in ownership are not reliably identified and/or strategic defaults are not differentiated from traditional defaults in the analysis. Chan (2001) provides the earliest evidence using mortgage servicing data from Chemical Bank on ARMs originated between November 1989 and January 1994 in NY, NJ and CT. She observes if and when a mortgage prepays. A prepayment can result from a borrower either selling the home and paying off the mortgage or refinancing the mortgage. While Chan cannot distinguish between home sales and refinances in her full data, she shows that for a subset of the ARMs originated in New York City where she merges in deeds records information that few prepayments of ARMs over this time period represent refinances. Mortgage defaults are treated as censored at the date of the default. The home's appraised value at origination is updated using county-level repeat-sales indices to create an updated LTV for each mortgage and demographic variables from the mortgage application (including the borrower's marital status, number of children, age, education and whether the borrower is a first-time homeowner) are used to control for many other determinants of household mobility. Using a proportional hazard framework, Chan finds that borrowers with current LTVs above 0.95 are 24

${ }^{51}$ See Cunningham et al (2013) and Valletta (2013) for examples of analysis of negative equity and labor markets. 
percent less likely to prepay (therefore move) over a three year period as compared to a similar borrower with a current LTV below 0.95 .

Engelhardt (2003) uses data from the National Longitudinal Survey of Youth (NLSY79) for the period 1985 to 1996 . This has the advantage of being a national survey. He uses address information from the confidential survey data to create his mobility measure. His intention is to restrict his mobility measure to moves involving owner to owner transitions and he imposes this restriction using a question in the NLSY79 on homeownership. His resulting mobility measure, therefore, is likely an imperfect indicator of whether a household moves and ownership is transferred. First, cases where the house is sold and the household transitions to renting are censored in the analysis. Second, in cases where the household moves but chooses to rent rather than sell the house, the NLSY79 does not identify the ownership status of the prior home. As such, Engelhardt has to censor these transitions as well. He attempts to distinguish between reductions in mobility due to declines in equity and to loss aversion. He controls for the origination rather than the current LTV, the extent of any nominal loss that has occurred since the house was purchased, and interaction effects between the origination LTV and loss variables. Since the nominal loss is based on self-reported house values which may be subject to measurement error, he instruments the nominal loss variables using implied losses based on repeat-sales house price indices. The IV strategy results in a significant increase in the standard errors of the nominal loss variables making inference more difficult. Engelhardt interprets his findings as relatively more supportive of loss aversion rather than equity effects as the primary source of the mobility friction from declining house prices.

A challenge for these earlier studies is that they predate the housing bust and so have limited amounts of negative equity in their data. Ferreira et al (2012) provide the first analysis that captures the initial effects of the housing bust. The authors use AHS data from 1985 to $2009 .^{52}$ The AHS is a

\footnotetext{
${ }^{52}$ This is an update to their earlier study Ferreira et al (2010) that used AHS data from 1985 to 2007.
} 
bi-annual survey over this period. Even including house price declines that occurred up to 2007, the reported incidence of negative equity is still only 3.7 percent. The AHS provides a self-reported house value. Ferreira et al (2012) acknowledge the likely measurement error in the self-reported house values and instrument this variable using a house value created from the appraised value updated using house price indices.

The AHS data is well suited for analyzing mobility in that it contains a wealth of demographic information about the household that can affect mobility. A challenge in the AHS data, though, is inferring changes in ownership of a home. The AHS is a panel of housing units, not households. The survey asks if a home is owned or rented, and for a home that is owned, changes in ownership can be observed if it is sold and a new household moves in. The "year purchase" variable confirms that the ownership has changed. However, if a home transitions from owned to rented, it is not immediately possible to know if the home has been sold since the year purchased variable is not reported in the case of a rental. If the rented home subsequently transitions back to owned, then it is possible to resolve whether and when the home was sold. As described in Ferreira et al (2012), in a significant number of cases of owned to rental transitions, the original owners of the home are observed returning at a later date, implying that it was not sold. Consistent with this finding, Bucks and Bricker (2013) report using panel data from the Survey of Consumer Finances (SCF) for 2007 and 2009 that roughly one-third of homeowners that moved between 2007 and 2009 did not sell the home they owned in 2007. If a different household is observed when the home reverts back to owned, then we can infer that it was sold, and the year purchased variable identifies the timing of the sale. However, if the home is still rented as of the last available survey, it is impossible to ascertain whether a sale took place or not. Ferreira et al $(2010,2012)$ decide to censor these transitions.

Another limitation of the AHS data is that for a household that moves it is not possible to know if the household either suffered an income loss or defaulted on the mortgage in the two-years 
between surveys. ${ }^{53}$ As such, moves associated with a traditional or a strategic default cannot be identified. An advantage, though, of their analysis is that all moves that are identified involve a transfer of ownership. However, for negative equity households their move definition suffers from two forms of misclassification. First, some of the identified moves occurred as the result of a traditional default where the home is purchased out of foreclosure to be used again as an owned residence. These moves are not the result of the negative equity but will be reflected in the negative equity coefficient since adverse income shocks are left-out of the specification ${ }^{54}$. Second, if following a strategic default a home is purchased out of a foreclosure to be used as a rental property (with no subsequent observed transition back to owned status), then this change in ownership is censored when it should be treated as a move resulting from the negative equity. ${ }^{55}$

With these caveats in mind, Ferreira et al $(2010,2012)$ find that negative equity is associated with around a 30 percent decline in mobility. Given the small fraction of households identified in negative equity, they do not test for variations in the degree of negative equity. In addition, the authors test for mobility effects from financial frictions arising from FRMs in a rising interest rate environment. Since most FRMs are neither assumable nor portable, as mortgage rates rise a household would have to pay a higher annual mortgage payment to move and take out an equivalent size new mortgage. Ferreira et al find that $\$ 1,000$ of additional annual mortgage payments reduces mobility by 16 percent. They cross-validate this finding by comparing it to the impact of the financial friction arising from California's Proposition 13 limitation on property taxes. They report that $\$ 1,000$ of annual property tax subsidy to a homeowner reduces mobility by 10 percent.

\footnotetext{
${ }^{53}$ Ferreira et al $(2010,2012)$ control for household income at the beginning of the two-year period used to track any move as well as the change in household income over the prior two-year period. ${ }^{54}$ If controlling for the other explanatory variables in the model the likelihood that a household suffers an adverse income shock is higher in areas with greater declines in house prices, then this will tend to create a positive bias to the negative equity coefficient.

${ }^{55}$ However, in cases of strategic default where the home is owner-occupied following the foreclosure, the move will be correctly recorded.
} 
Andersson and Mayock (2013) provide the cleanest measures of negative equity as well as moves that involve a sale of the home. A limitation of their study is that it covers only properties in Florida. However, their data span the period from 1999 to 2011, and given the significant declines in Florida house prices in the bust, they have the largest sample of negative equity households. Unlike the AHS and NLSY79 surveys which rely on self-reported house values, they have annual assessed values for each property as of January of each year. To match the timing of their other data, they update these values to June using county-level repeat sales price indices. Their mobility variable is derived from deeds records data provided by DataQuick, allowing them to identify all home sales. ${ }^{56}$ They merge this to annual credit bureau data (for June) that allows them to observe the remaining balance and delinquency status of each mortgage. This allows the authors to create a relatively clean updated LTV. They also distinguish between home sales that are associated with a mortgage delinquency or not. However, they do not attempt to distinguish between traditional and strategic defaults. They classify a home sale without a default as a "voluntary" sale, and a home sale with a default as an "involuntary" sale. This classification involves potential measurement error in that strategic defaults are categorized as involuntary rather than voluntary.

The steep declines in Florida house prices also allow the authors to examine both the effects of the incidence and magnitude of negative equity on mobility. They report that 19 percent of their households are in negative equity, with 10 percent having an updated LTV of 1.3 or higher. They estimate logit and multinomial logit models where they control for the borrower's origination credit score, age and years in the home. They also include time fixed effects. Negative equity is found to monotonically reduce the likelihood of voluntary moves, and significant negative equity (LTV in

\footnotetext{
${ }^{56}$ A sale is identified regardless of whether the home is subsequently used for owned or rental housing. In addition, if a household moves out but does not sell the home, this is correctly identified as no sale.
} 
excess of 1.3) to increase the likelihood of involuntary moves. ${ }^{57}$ Overall, they estimate that mobility declined by roughly 25 percent due to reductions in home equity.

As indicated earlier, the definition of a move is important for the estimated relationship between negative equity and mobility. Schulhofer-Wohl (2011), Bucks and Bricker (2013) and Coulson and Grieco (2013) focus on mobility defined as changes in household residence regardless of whether the home is sold. This definition of a move is more appropriate for investigating the potential impact of negative equity on the labor market than its effect on the housing market. Schulhofer-Wohl uses the AHS estimation sample from Ferreira et al (2010) and recodes the censored transitions from owned to rental as a move. As Ferreira et al (2012) demonstrate, this definition includes many temporary moves where a household leaves, rents out the house and returns at a later date. Refocusing the mobility definition to the household and not the home, Schulhofer-Wohl reports that negative equity is in fact positively related to mobility.

This finding is corroborated in Coulson and Grieco (2013) who use data from the PSID covering the period from 1999 to 2009. Mobility again is defined as a change of residence by a household. Like the AHS, the PSID allows Coulson and Grieco to control for several demographic variables that might be expected to impact mobility. Similar to the AHS data, default is not controlled for in the analysis. Coulson and Grieco report that their mobility measure increases with the degree that the household is in negative equity. Given the evidence in Chan (2001) and Andersson and Mayock (2013), the contrast in results between the two mobility definitions is likely driven by default related moves, as well as temporary moves resulting from adverse income shocks. Consistent with this, Bucks and Bricker (2013) using SCF data report that nearly half of homeowners with negative equity that experienced an unemployment spell moved between 2007

\footnotetext{
${ }^{57}$ Molloy and Shan (2013) examine panel data on household credit files and find that roughly 50 percent of households move within two years of the start of a foreclosure. Only a small fraction of households appear to move back in with their parents.
} 
and 2009. Future work will have to disentangle the effects of strategic from traditional defaults to better isolate the role of negative equity as opposed to adverse income shocks on housing turnover.

The financial crisis resulting from the housing bust led to aggressive official responses in terms of fiscal and monetary policy. As a consequence, mortgage rates reached very low levels with 30-year FRMs being offered as low as 3.35 percent in November/December 2013. For borrowers with FRMs that still had sufficient equity in their house, this steep decline in mortgage rates created a strong incentive to refinance their mortgages. However, for borrowers with agency mortgages guaranteed by Freddie Mac or Fannie Mae, many no longer had sufficient equity to fund the required down payment on a refinance. In response, the Home Affordable Refinance Program (HARP) was introduced in March 2009 to allow these borrower to refinance so long as they had a clean payment history and had originated their mortgage prior to June 2009. In December 2011, changes were made to the HARP program to expand its eligibility and reduce the associated fees. As of December 2013, 3.1 million mortgages have refinanced under HARP. ${ }^{58}$ Borrowers with FHA mortgages can use a streamline refinance program that does not depend on the borrower's current LTV. Since 2009, 1.5 million high LTV FHA borrowers have refinanced using this program. ${ }^{59}$ Combined, a total of 4.6 million high LTV borrowers have refinanced to a lower interest rate. As of January 2014, prime conforming 30-year FRMs with coupon rates of roughly 4.5 percent or less had aggregate balances of $\$ 2.3$ trillion.

The HARP and FHA streamline refinance programs have been successful in helping to circumvent the friction to refinancing caused by the steep decline in house prices. Through refinancing, these impacted borrowers were able to significantly lower their required monthly

\footnotetext{
${ }^{58}$ See FHFA (2013).

${ }^{59}$ See HUD (2013).
} 
mortgage payments. ${ }^{60}$ This is clearly beneficial to these households. It is important to note, however, that the borrowers with agency mortgages who did a normal refinance along with those refinancing under the HARP program received a non-assumable and non-portable FRM. An implication is that as the economy improves and mortgage rates normalize, these borrowers will face a large financial friction to moving due to their below market rate mortgages. This interest rate friction was documented by Quigley (1987) and updated by Ferreira et al $(2010,2011) .{ }^{61}$ In contrast, since FHA mortgages are assumable, their streamline refinance program should not generate this interest rate lock-in effect.

\subsection{Negative Equity and Housing Investment}

In addition to affecting housing turnover, negative equity may also reduce housing investment. Housing investments improve the flow of housing services and for the duration of time that the household expects to live in the home, the household directly receives the benefits from the investments. In fact, if the horizon of the household's expected stay exceeds the useful life of the investment, then the household can expect to receive the full value of the investment. In many cases, though, due to the durable nature of many investments, the service flow from the investment may be expected to continue beyond the household's remaining tenure. In these cases, if there was no way for the household to capture the value of the remaining service flow when it sells the home, then this would reduce the incentives for the household to make long-lived investments.

Capitalization of housing investments into the house price acts to extend the horizon of the household when it is considering housing investment decisions. This helps to promote an efficient

\footnotetext{
${ }^{60}$ Borrowers refinancing under HARP on average lower their monthly mortgage payment by $\$ 137$, see Zhu (2012).

${ }^{61}$ Assuming that these borrowers would have to give up the $\$ 137$ per month in lower monthly mortgage payments in order to move, this would imply an annual financial friction of $\$ 1,644$. Using the estimates from Ferreira et al $(2010,2012)$ this would be expected to reduce mobility by 16 percent.
} 
investment profile by the household regardless of its expected tenure in the home. ${ }^{62}$ However, for capitalization to support efficient investment, at the time of the investment decision the homeowner must expect to have a positive equity position when the home is to be sold. That is, the homeowner needs to be fully exposed to any gains or losses in the value of the home that are associated with the investment decision. ${ }^{63}$ In normal housing markets, this is not a binding constraint since the homeowner's initial equity tends to rise over time due to a combination of house price increases and debt amortization.

Negative equity may reduce housing investment for a variety of reasons. First, negative equity puts the borrower at risk of a default in the future if the borrower suffers an adverse income shock. In the event of a default, any capitalization from a housing investment will first go to the lender. As a result, negative equity creates an agency problem between the lender and the household. The lender would like the household to continue to make costly housing investments, but the lender has no direct control over these investment decisions until they take title to the property through foreclosure. Second, for those types of investments that can be delayed with little impact on the immediate flow of housing services, the household may choose to postpone these investments in order to create precautionary savings (see Carroll et al, 2012). Third, households may need to use the equity in their home to finance larger investment projects and underwater households do not have access to this source of collateralized financing. Finally, households in negative equity have experienced a wealth loss that can lead to reduced consumption in general, and housing investments in particular. We focus here specifically on the negative equity instead of the wealth declines since

\footnotetext{
${ }^{62}$ See Fischel (2001).

${ }^{63}$ An important question is whether making mortgage loans recourse mitigates the need for the borrower to expect to have a positive equity stake at the time of sale. We will return to this question.
} 
the negative equity results from a feature of the mortgage contract - no maintenance margin whereas the wealth effects are less dependent on the structure of the mortgage. ${ }^{64}$

Prior to the housing bust, given the paucity of negative equity, research focused on the behavior of maintenance and improvement expenditures (hereafter housing investment) to adverse income shocks instead of adverse equity shocks. ${ }^{65}$ For most categories of housing investment, the investment can be deferred without a first-order reduction in the flow of housing services. This suggests that the timing of housing investment could be used to help smooth consumption in the face of transitory income shocks. Gyourko and Tracy (2006) use AHS data from 1985 to 1993 to estimate the response of housing investment to transitory income shocks. Using the panel structure of the AHS data they estimate a heterogeneous growth model for household income. This allows them to estimate the transitory component of the income residual. While they find a statistically significant response of housing investment to the estimated transitory income shocks, this component plays a relatively minor overall role in the household's overall strategy for smoothing its consumption. ${ }^{66}$

Turning to negative equity effects on housing investment, Haughwout et al (2013) and Melzer (2012) both use the Consumer Expenditure Survey (CEX) data to investigate this relationship. ${ }^{67}$ The CEX consists of short-panels - essentially four consecutive quarterly surveys - of households. An advantage of the CEX is that it has detailed information on a wide range of types of housing investment as well as detailed demographic information on the household. Given the lumpy

\footnotetext{
${ }^{64}$ The potential wealth effect is influenced by one feature of the mortgage contract - whether the lender has recourse or not. In the case of a non-recourse mortgage, the potential negative wealth effect is limited to the borrower's down payment. In the case of a recourse mortgage, the lender can petition to pursue the borrower's other financial assets to satisfy any deficiency.

${ }^{65}$ An earlier literature related property tax delinquencies, which in the extreme can generate negative equity, to housing disinvestment and ultimately abandonment. See White (1986), O'Flaherty (1993) and Scafidi et al (1998).

${ }^{66}$ They also find that housing investment is positively related to estimated permanent income shocks. This can be interpreted as a wealth effect on housing investment.

${ }^{67}$ Haughwout et al use data from 2007 to 2012, while Melzer uses data from 2006 to 2011.
} 
nature of most housing investments, Haughwout et al aggregate these expenditures across the four surveys, whereas Melzer estimates his specification using the quarterly data. Negative equity must be inferred from the household's self-reported house value and estimates of the current outstanding balances for all loans secured by the house. Haughwout et al create a negative equity indicator based on the initial quarter survey information and then instrument this using negative equity indicators based on the remaining three quarters. They argue that an important component of the measurement error in self-reported house values is transitory. Melzer does not try to address measurement error. Another specification difference is that Haughwout et al control for household income whereas Melzer controls for total household expenditures. The IV results from Haughwout et al indicate that negative equity is associated with a 74 percent $(\$ 2,610)$ annual reduction in housing investment. Melzer reports a much smaller impact of 30 percent or $\$ 800$ per year. The income elasticity reported by Haughwout et al of 0.58 exceeds the elasticity of 0.42 reported in Gyourko and Tracy (2006).

An interesting question is whether we can identify the channels that may be generating this estimated effect for negative equity on housing investment. Earlier we discussed that these channels include the agency problem regarding the investment decision, a demand for precautionary savings, collateral constraints on borrowing, and wealth effects. The precautionary savings, collateral and wealth channels have the feature that they would also be expected to impact other significant durable purchases such as home furnishings and vehicles. However, since these categories of durable goods are not tied to the home, they should not be impacted by agency problems arising from 
negative equity. ${ }^{68}$ Melzer reports no significant impacts of negative equity on either vehicle purchases or home furnishings and equipment expenditures. These results provide indirect support for the agency channel being important for the estimated negative equity and housing investment relationship. However, the other channels through which declining house prices may impact durable goods purchases would still be expected to lead to a reduction in expenditures in these categories.

There are two ways in which lenders can protect themselves from this agency problem regarding housing investments. The first is to require larger down payments. This would reduce the likelihood that the borrower ends up in negative equity. The second is to attempt to make the borrower internalize the consequence of a decision not to maintain the property even after the borrower no longer has any home equity. A potential legal remedy that attempts to do this is making the mortgage a recourse loan. Recourse mortgages allow the lender to file a deficiency judgment against the borrower for any shortfall between the remaining mortgage balance and the proceeds from selling the home in foreclosure. The lender may satisfy the deficiency judgment using the borrower's other financial assets.

In practice, recourse is unlikely to discipline borrower housing investment decisions in most circumstances. For recourse to provide an effective legal remedy to the agency problems created by negative equity, three things need to hold. First, the borrower must be aware that the mortgage is a recourse loan and understand the potential financial consequences. If borrowers are not aware of this legal right by lenders, then recourse will not affect their housing investment decisions. Haughwout et al (2013) report that among U.S. borrowers with recourse mortgages only 56 percent

\footnotetext{
${ }^{68}$ There are some measurement issues with these two variables. The home furnishings category include large appliances such as refrigerators that are installed but not as part of a contracted project. Similar installed appliances that are part of a contracted project are treated as home improvement expenditures. This creates an asymmetry in the treatment of these appliances. Also, the category vehicle purchases includes both purchases and leases. For leases it is not possible to distinguish between a new lease and an existing lease. This makes it impossible to isolate new spending decisions on vehicles.
} 
correctly identified the recourse status of the mortgage. ${ }^{69}$ Second, at the time that the borrower is considering making a costly maintenance decision, the borrower must expect to have financial assets that will exceed the amount of negative equity at the time of the foreclosure completion. If the negative equity already exceeds the borrower's financial assets, then any further decline in the value of the home due to a decision not to carry out a specific maintenance project will not have any impact on the expected collection from a deficiency judgment. Haughwout et al (2013) report that for borrowers with at least $\$ 10,000$ in negative equity in their CEX estimation sample, only 22 percent had current financial assets that exceeded $\$ 10,000$. Finally, filing for a deficiency judgment is costly with the specific expense varying by state. Lenders will only file if the expected claim exceeds the filing costs. This suggests that lenders will only likely file in cases with relatively large deficiency amounts. The FHFA's Inspector General Report (2012) indicated that the GSEs file for deficiency judgments in 2011 for only 10.3 percent of all foreclosures involving mortgages guaranteed by the GSEs.

The impact of negative equity on housing investment may help to explain the findings of negative price externalities for foreclosures on nearby properties. Much of this literature focuses on the flows into foreclosure, which we discuss in the next section. However, Gerardi et al (2012) expand the focus to look at the stock of seriously delinquent properties. They find that the negative price externality is modest and emerges with serious delinquency, peaks during foreclosure and dissipates within a year following the sale by the lender. An explanation for the magnitude and timing of the effect may be the reduced investment by underwater borrowers. Unfortunately, the CEX data does not have information on borrower delinquency, so Melzer (2012) and Haughwout et al (2013) cannot determine if the disincentive to make costly housing investments has its onset when a borrower enters negative equity, or only later when the borrower reaches some level of

${ }^{69}$ This is from the 2013 Survey of Consumer Expectations. 
delinquency. In addition, the finding by Gerardi et al (2012) that the negative externality dissipates within a year following a sale by the lender could be explained if most of the foregone maintenance is made up by the new owner. ${ }^{70}$ This possibility points to a fruitful avenue for future research using the AHS where one can observe the maintenance decisions by the subsequent owner.

Before turning to the issue of foreclosures, it is worth discussing how the structure of mortgage contracts may impact the social benefits from homeownership. A wide range of government policies have been directed towards increasing the homeownership rate on the belief that homeowners take better care not just of their properties but also of their communities. ${ }^{71}$ Fischel (2001) argues that homeowners make these costly investments because they believe that the investments will enhance the value of their homes. This capitalization effect, though, assumes that the homeowner has positive equity. Haughwout et al (2010) show that following the housing bust the median owner in several metro areas located in the boom/bust states had negative equity. In addition to a diminished incentive to invest in their homes, pervasive negative equity could lead to under investment in local public infrastructure. This would be another area for future research.

\section{Foreclosures}

Figure 11 shows the dramatic increase in foreclosures following the housing market bust.

The foreclosure rate rose rapidly from 0.6 percent of mortgages at the start of 2007 to 3.0 percent in 2010, peaking at 3.9 percent in 2012 .

\footnotetext{
${ }^{70}$ Alternatively, the lender may remedy some of the maintenance issues prior to the sale.

${ }^{71}$ Homeowners tend to vote for local school bond issues (Bergstrom et al 1982 and Hilber and Mayer, 2009). Homeowners are also more likely to participate in civic activities such as voting in local elections (DiPasquale and Glaeser, 1999).
} 


\subsection{The Distribution of Foreclosures}

There are many reasons to expect a pronounced spatial pattern in foreclosures. As mentioned earlier, many studies provide evidence that sub-prime mortgage lending was disproportionately made in non-white and poorer neighborhoods. These loans, of course, turned out to be much quicker to default during the bust phase of the housing cycle. ${ }^{72}$ Figure 12 provides an illustration of the geographic concentration of default in predominantly black and Hispanic neighborhoods in New York City. As in Figure 8, the shading shows the share of black or Hispanic residents in each census tract, but here, each dot represents one residential foreclosure filing issued in 2009. As expected, Figures 8 and 12 look remarkably similar. Haughwout et al (2012) also find a spatial pattern in the prevalence of investor-originated loans, which ex post turned out to be quick to default when house prices began to fall.

House price cycles were more pronounced in some places, leading to a higher probability of negative equity. Income shocks were also spatially concentrated, in many cases in the same areas as the biggest house price cycles. These phenomena varied significantly both across and within metropolitan areas. An important line of inquiry is the extent to which the high foreclosure rates for certain vintages of nonprime mortgages were due to weaker underwriting of these mortgages - both in observable risk characteristics and unobservable dimensions - and how much to the deteriorating economic environment. Haughwout et al (2008) find that observed factors explain less than half of the sharp rise in early subprime defaults between 2003 and 2007 . Around 70 percent of the explained variation is due to economic factors not to borrower or loan risk characteristics. The authors speculate that non-declared investors might explain the large unexplained component of early defaults. Palmer (2014) extends the analysis of Haughwout et al (2008) by looking at default behavior over several years following origination. Palmer finds that origination year vintage effects

\footnotetext{
${ }^{72}$ For example, see Chan et al (2013) and Bayer et al (2013).
} 
capturing any unobserved underwriting quality explain little of the observed differences in default behavior.

Property tax lien foreclosures have also become an increasing problem in recent years. While distinct from mortgage foreclosures, they share some of the same underlying causes, and have similar external impacts on the surrounding neighborhood. A local government can generally place a tax lien on the property if a homeowner is delinquent for more than one year on property taxes or other municipal charges. These tax liens have priority over any mortgage and give the lien holder the right to foreclose in order to recover the deficiency.

Failure to pay property taxes has been discussed earlier in the context of reverse mortgages. For forward (i.e., non-reverse) mortgages, lenders typically require an escrow account that covers property taxes and insurance. However, the majority of subprime loans made prior to 2008 did not include an escrow account, perhaps to make the monthly loan payment seem more affordable (National Consumer Law Center, 2012). Thus, higher cost subprime mortgage borrowers, who were more prevalent in low income and non-white communities, not only had higher mortgage default rates, they are also more likely to be at risk of a tax deficiency. Because local governments tend to impose substantial interest and penalties on any deficiencies and have first-lien priority, lenders have an incentive to pay any non-escrowed taxes, so long as the home's expected present value at a mortgage foreclosure auction exceeds the expected present value of the tax payments. Of course, that condition is less likely to be met in neighborhoods suffering large declines in property values, leading to higher rates of tax foreclosure and all the negative spillover effects associated with mortgage foreclosure that we discuss below. ${ }^{73}$

\footnotetext{
${ }^{73}$ The sale of property tax liens to third party investors, and in some cases, their securitization has led to a host of other problems affecting not only properties with mortgages. See National Consumer Law Center (2012) for more details.
} 


\subsection{Foreclosure externalities}

An extensive literature has developed around the important question of whether there exists a negative "externality" of a foreclosure property on the prices of nearby houses (Immergluck and Smith, 2006a; Schuetz et al, 2008; and Campbell et al, 2011). This question is important for both positive and normative reasons. On the positive side, understanding spillovers can help to explain observed spatial concentrations in price declines and in mortgage defaults. In addition, the existence of significant spillovers of foreclosures onto neighboring property prices could lend support to the case for interventions to prevent foreclosures in the future, ranging from reforms of the mortgage contract itself to ex post interventions intended to reduce foreclosures after a market downturn.

In general, these studies have found such externalities, with the price of nearby houses falling as more properties in the neighborhood are foreclosed upon. For example, Campbell et al (2011), using sales from Massachusetts over the period 1987-2009 estimate hedonic price regressions, augmented by information on the number of foreclosures within small distances from the unit in question. In so doing they are able to control for the effect of local demand shocks, which have the potential to lead to a spurious correlation between foreclosures and local price declines. The results indicate that an additional foreclosure within 0.05 miles (88 yards) of a nonforced sale reduces the price that the unit will command by about 1 percent.

More work is required to completely identify the channel through which these externalities are produced. Several hypotheses seem plausible. A natural candidate is that increased foreclosures shift the supply curve outward, leading to lower prices in the neighborhood. Two recent studies find support for this hypothesis. Hartley (2011) uses data from Chicago and finds no effect of multifamily foreclosures on the sales price of nearby single-family units. Given the segmentation between demands for those two types of housing, the negative spillover identified in other work must be attributable to a supply effect. 
Anenberg and Kung (2013) use national data and exploit the timing of REO (Real Estate Owned - that is properties owned by banks) listings to estimate the effect of foreclosures on neighboring properties. The authors find that only when the property is actually listed for sale - not before it is listed or after it is sold - do neighboring prices decline. In this case, the authors find a 1.6 percent reduction in sale prices of nearby homes when the REO is listed, an effect which diminishes with distance from the REO and becomes zero at roughly $1 / 2$ mile. As noted, the authors find that the price declines are temporary and reverse as soon as the foreclosure property is sold. The authors argue that this overall temporal pattern is consistent with the externality being produced by price competition.

As discussed earlier, a second possible channel to consider is diminished maintenance of the foreclosed structure, creating a localized disamenity that Gerardi and Willen (2013) argue is important. The bids of prospective buyers of neighboring properties may be reduced by proximity to an under-maintained unit in the foreclosure process, which creates a neighborhood negative spillover. Interestingly, Anenberg and Kung (2013), while finding that the spillover from foreclosed properties is primarily a supply shift, conduct additional analysis on high density, low price neighborhoods and find that in those areas the data support the existence of a disamenity effect. Foreclosure properties in such neighborhoods are probably in poorer condition to begin with, and they may be especially likely to generate a negative spillover with a further reduction in maintenance.

We do not know much about the timing of this reduction in maintenance, although Meltzer (2010) and Haughwout et al (2013) find a diminution in housing investment from the onset of negative equity, at which point the owner's incentive to maintain becomes less clear-cut. We also do not know how persistent these shortfalls are. Do new owners make them up? The persistence of the neighborhood effects identified in Campbell et al implies that they may not do so immediately. Another potential channel through which foreclosures may affect neighboring property values is 
crime. Ellen et al (2013) and Immergluck and Smith (2006b) find that neighborhoods with additional foreclosures experience increases in crime, which presumably will reduce property values.

A second important effect of the spatial concentration of foreclosures is reduced property tax revenues because the owner of the foreclosed property has little incentive to continue making tax payments on a property that he will not own much longer. In addition, the subsequent reduction in neighboring property values contributes to further reductions in the tax base, leading to diminished services or higher tax rates, each of which will put further downward pressure on home values. This is another mechanism that can generate the negative price externalities found in previous work, although the precise spatial patterns found by previous authors suggest that at least some mechanisms are operating at a geographic scale smaller than the municipality.

Beyond the effects of foreclosure on locations, of course, is the significant effect on individual borrowers who must vacate their homes. These individuals experience large reductions in their credit ratings that take many years to repair (Brevoort and Cooper, 2013), reducing their ability to smooth earnings shocks and invest in their futures. The impact on other household members who are also forced to move may also be substantial. For example, Been et al (2011) find that New York City elementary and middle school students living in foreclosed buildings were, all else equal, more likely to switch schools (generally regarded by experts as detrimental), and on average, they switched to schools offering academically weaker peers.

The rapidly-growing literature on foreclosure externalities has produced some important facts. We now know that foreclosures exert a negative effect on nearby properties - generally those within half a mile or less of the foreclosed property. Those external effects appear to be short-lived, and may be primarily attributable to price competition rather than a disamenity effect. This suggests that isolated foreclosures will not have persistent, widespread effects on most neighborhoods. However, it is worth recalling that during the recent bust foreclosures themselves tended to be 
spatially concentrated, especially in the poorer, denser neighborhoods that received large amounts of subprime credit. The existing evidence clearly indicates that these properties will be undermaintained, and in these neighborhoods there exists some evidence that spillovers are more persistent and more related to the disamenity. More research in this area is likely warranted to ensure that we thoroughly understand these important dynamics.

\section{Conclusion}

Our review of the effects of mortgage finance on spatial patterns of residential activity indicates that while we understand much of how these effects play out, we still have much to learn. The events of the 2000s provide a wealth of information on which to base future analyses of these important questions. One element that we have not discussed much is whether alternatives to the current form of mortgages could improve outcomes.

Despite many innovations and changes to the system of mortgage finance in the U.S., the core product, the 30-year amortizing mortgage that replaced the standard short term balloon mortgage in the 1930s, has remained essentially unchanged for almost a century. In the interim, American society and the U.S. economy have undergone fundamental changes. Discrimination and differential outcomes by race and ethnicity have become more repugnant to society, leading to a more acute focus on the role of mortgage finance in perpetuating disparities. The increasingly high cost of medical and long term care, the sustained increases in longevity, and the declining prevalence of traditional defined benefit pensions have highlighted housing's role as an important source of retirement and precautionary saving. The last twenty years have seen dramatic fluctuations in housing prices and these have had greater impact on households as the ability to borrow against 
home equity has expanded. Further, recent decades have seen substantial increases in income inequality that may well be exacerbated by the current system of mortgage finance and by some aspects of housing-related public policies, including the tax code and mortgage industry regulation.

Ideally, an alternate mortgage instrument would alleviate the down payment constraint associated with the transition to homeownership, eliminate any scope for discrimination in mortgage qualification or pricing, allow households to easily tap into accumulated home equity while also serving as an automatic vehicle for saving, reduce the frictions and costs arising from negative equity and foreclosure, and reduce the exposure of households to fluctuations in the housing market. Such an instrument does not yet exist, although several proposals have the potential to address a subset of these issues. The housing partnerships proposed by Caplin et al (1997) and described earlier in this chapter can ease the transition to homeownership, and reduce housing asset risk and the consequences of negative equity. Shiller (2008) has proposed continuous work out mortgages (CWMs) in which the mortgage balance and payment schedule would systematically and continuously adjust to a local home price index, as well as other economic indices such as the unemployment rate, in a way that preserves some home equity and payment affordability for the borrower. For lenders, CWMs may be attractive as they reduce the risk of foreclosure costs and inadequate home maintenance.

As Shiller (2014) notes, the development of new mortgage forms is costly while the benefits are difficult to capture privately. Whether these and other mortgage product innovations will grow in importance depends critically on research, as well as on industry and government support for experimentation. The 30-year mortgage that is now taken for granted was the result of government intervention in the mortgage market and further beneficial innovations will not necessarily arise naturally from the private sector. 


\section{References}

Andersson, Fredrik, and Tom Mayock. "How Does Home Equity Affect Mobility?" Working Paper. Office of the Comptroller of the Currency, September, 2013.

Andrews, Dan, and Aida Caldera Sanchez. "The Evolution of Homeownership Rates in Selected OECD Countries: Demographic and Public Policy Influences." OECD Journal Economic Studies 2011 (2011): 207-243.

Anenberg, Elliot, and Edward Kung. "Estimates of the Size and Source of Price Declines Due to Nearby Foreclosures." Board of Governors, December, 2013.

Annual Report to Congress Regarding the Financial Status of the FHA Mutual Mortgage Insurance Fund Fiscal Year 2010. U.S. Department of Housing and Urban Development, 2013.

Apgar, William, and Mark Duda. "The Twenty-fifth Anniversary of the Community Reinvestment Act: Past Accomplishments and Future Regulatory Challenges." Economic Policy Review 9 (June 2003): 169-91.

Avery, Robert B., Kenneth P. Brevoort, and Glenn B. Canner. "Higher-priced Home Lending and the 2005 HMDA Data." Federal Reserve Bulletin 92 (2006): A123-A166.

------, Paul S. Calem, and Glenn B. Canner. "The Effects of the Community Reinvestment Act on Local Communities." In Proceedings 878. Federal Reserve Bank of Chicago, 2003.

Barr, Michael S. "Credit Where It Counts: The Community Reinvestment Act and Its Critics." New York University Law Review 80 (May 2005): 513-652.

Bayer, Patrick, Fernando Ferreira, and Stephen L. Ross. "The Vulnerability of Minority Homeowners in the Housing Boom and Bust." Working Paper No. 19020. NBER, May, 2013. http://www.nber.org/papers/w19020.

-----, Fernando Ferreira, and Stephen L. Ross. "Race, Age and High Cost Mortgage Lending: Borrower Experiences Leading up to the Crisis." Working Paper. Duke University, 2014.

Been, Vicki, Ingrid Gould Ellen, Amy Ellen Schwartz, Leanna Stiefel, and Meryle Weinstein. "Does Losing Your Home Mean Losing Your School? Effects of Foreclosures on the School Mobility of Children." Regional Science and Urban Economics 41 (July 2011): 407-414.

Bergstrom, Theodore C., Daniel L. Rubinfeld, and Perry Shapiro. "Micro-Based Estimates of Demand Functions for Local School Expenditures." Econometrica 50 (September 1982): 11831205.

Bernanke, Ben S., Board of Governors. "The Community Reinvestment Act: Its Evolution and New Challenges." In Community Affairs Research Conference. Washington, D.C., March 30, 2007. http://www.federalreserve.gov/newsevents/speech/bernanke20070330a.htm.

Bocian, Debbie Gruenstein, Keith S. Ernst, and Wei Li. "Race, Ethnicity and Subprime Home Loan Pricing." Journal of Economics and Business 60 (Jan-Feb 2008): 110-124.

Bond, Philip, Ronel Elul, Sharon Garyn-Tal, and David K. Musto. "Does Junior Inherit? Refinancing and the Blocking Power of Second Mortgages." Working Paper No. 13-3/R. Federal Reserve Bank of Philadelphia, June, 2013. https://www.philadelphiafed.org/research-and-data/publications/workingpapers/2013/wp13-3R.pdf.

Bourassa, Steven C., and William G. Grigsby. "Income Tax Concessions for Owner-Occupied Housing." Housing Policy Debate 11, no. 3 (2000): 521-546.

------, Donald R. Haurin, and Patric H. Hendershott. "Mortgage Interest Deductions and Homeownership: An International Perspective." Journal of Real Estate Literature 21, no. 2 (2013): 181-203. 
Bradley, Michael G., Amy Crews Cutts, Biplab K. Gosh, and Wei Liu. "Uncovering the Risks of Strategic Default." Working Paper. CoreLogic, 2012.

Brevoort, Kenneth P., and Cheryl R. Cooper. "Foreclosures's Wake: The Credit Experience of Individuals Following Foreclosure." Real Estate Economics 41, no. 4 (2013): 747-792.

Bucks, Brian K., and Jesse Bricker. "Household Mobility over the Great Recession: Evidence from the U.S. 2007-09 Survey of Consumer Finances Panel." Finance and Economics Discussion Series 2013-53. Federal Reserve Board, 2013.

Campbell, John Y., Stefano Giglio, and Parag Pathak. "Forced Sales and House Prices." American Economic Review 101 (August 2011): 2109-2131.

Caplin, Andrew, Sewin Chan, Charles Freeman, and Joseph Tracy. Housing Partnerships. Cambridge, MA, MIT Press, 1997.

------, Charles Freeman, and Joseph Tracy. "Collateral Damage: Refinancing Constraints and Regional Recessions." Journal of Money, Credit, and Banking 29 (November 1997): 496-516.

Chan, Sewin. "Spatial Lock-In: Do Falling House Prices Constrain Residential Mobility?" Journal of Urban Economics 49 (May 2001): 567-586.

------, Michael Gedal, Vicki Been, and Andrew Haughwout. "The Role of Neighborhood Characteristics in Mortgage Default Risk: Evidence from New York City." Journal of Housing Economics 22 (June 2013): 100-118.

Chatterjee, Satyajit, Dean Corbae, Makato Nakajima, and Jose-Victor Rios-Rull. "A Quantitative Theory of Unsecured Consumer Credit With Risk of Default." Econometrica 75 (November 2007): 1525-1589.

Consumer Financial Protection Board. Reverse Mortgages. Report to Congress, 2012.

Coulson, N. Edward, and Paul L.E. Grieco. "Mobility and Mortgages: Evidence from the PSID." Regional Science and Urban Economics 43 (January 2013): 1-7.

Courchane, Marsha J. "The Pricing of Home Mortgage Loans for Minority Borrowers: How Much of the APR Differential Can We Explain?" Journal of Real Estate Research 29 (Oct-Dec 2007): 399-439.

------, Brian Surette, and Peter Zorn. "Subprime Borrowers: Mortgage Transitions and Outcomes." Journal of Real Estate Finance and Economics 29 (December 2004): 365-392.

Cox, Donald, and Tullio Jappelli. "Credit Rationing and Private Transfers: Evidence From Survey Data." Review of Economics and Statistics 72 (August 1990): 445-454.

Crawford, Allan, Cesaire Meh, and Jie Zhou. "The Residential Mortgage Market in Canada: A Primer." Financial System Review, December 2013, 53-63.

Cunningham, Chris, and Robert R. Reed. "Negative Equity and Wages." Regional Science and Urban Economics 43 (November 2013): 841-849.

Davidoff, Thomas. "Maintenance and the Home Equity of the Elderly." Working paper, 2006. http:/ / flatbush.sauder.ubc.ca/REErevise.pdf.

-----. "Home Equity Commitment and Long-Term Care Insurance Demand." Journal of Public Economics 94 (February 2010): 44-49.

-----. "Can 'High Costs' Justify Weak Demand for the Home Equity Conversion Mortgage?" Working Paper. University of British Columbia, Sauder School of Business, October, 2013. http://ssrn.com/abstract $=2146988$.

-----. "Supply Elasticity and the Housing Cycle of the 2000s." Real Estate Economics 41 (Winter 2013): 793-813.

-----. "Reverse Mortgage Demographics and Collateral Performance." Working Paper, February, 2014. http://ssrn.com/abstract=2399942.

DiPasquale, Denise, and Edward L. Glaeser. "Incentives and Social Capital: Are Homeowners Better Citizens?" Journal of Urban Economics 45 (May 1999): 354-384. 
Donovan, Colleen, and Calvin Schnure. "Locked in the House: Do Underwater Mortgages Reduce Labor Market Mobility?" Working Paper, May, 2011.

Ellen, Ingrid Gould, Johanna Lacoe, and Claudia Ayanna Sharygin. "Do Foreclosures Cause Crime?" Journal of Urban Economics 74 (March 2013): 59-70.

Engelhardt, Gary. "Nominal Loss Aversion, Housing Equity Constraints, and Household Mobility: Evidence from the United States." Journal of Urban Economics 53 (January 2003): 171-195.

-----. "House Prices and the Decision to Save for Down Payments." Journal of Urban Economics 36 (September 1994): 209-237.

------, and Christopher J. Mayer. "Intergenerational Transfers, Borrowing Constraints, and Saving Behavior: Evidence From the Housing Market." Journal of Urban Economics 44 (July 1998): 135-157.

Eriksen, Michael D., Nadia Greenhalgh-Stanley, and Gary V. Engelhardt. "Home Safety, Accessibility, and Elderly Health: Evidence From Falls." Working Paper. Texas Tech University, 2013. http://meriksen.ba.ttu.edu/Papers/Falls_Eriksen.pdf.

Experian-Oliver Wyman Market Intelligence Reports. "Understanding Strategic Default in Mortgages Part I." 2009 Topical report series, August, 2009. http://www.hofinet.org/upload_docs/ExperianOliverWyman2009OW_Strategic_Mortgage_Default_Study.pdf.

Fairlie, Robert W., and Harry A. Krashinsky. "Liquidity Constraints, Household Wealth, and Entrepreneurship Revisited." Review of Income and Wealth 58 (June 2012): 279-306.

Fannie Mae. National Housing Survey Q1-2013 Data Summary, April, 2013.

Ferreira, Fernando, Joseph Gyourko, and Joseph Tracy. "Housing Busts and Household Mobility." Journal of Urban Economics 68 (July 2010): 34-45.

------, Joseph Gyourko, and Joseph Tracy. "Housing Busts and Household Mobility: An Update." Economic Policy Review 18 (November 2012): 1-15.

FHFA's Oversight of the Enterprises' Efforts to Recover Losses from Foreclosure Sales. Federal Housing Finance Agency, Office of Inspector General. Audit Report: AUD-2013-001, 2012.

Fischel, William A. The Homevoter Hypothesis: How Home Values Influence Local Government Taxation, School Finance and Land-Use Policies. Cambridge, Harvard University Press, 2001.

Genesove, David, and Lu Han. "A Spatial Look at Housing Boom and Bust Cycles." In Housing and the Financial Crisis, edited by Edward Glaeser and Todd Sinai, 105-142. Chicago, National Bureau of Economic Research, 2013.

------, and Christopher J. Mayer. "Equity and Time to Sale in the Real Estate Market." American Economic Review 87 (June 1997): 255-269.

Gerardi, Kristhpher S., Eric Rosenblatt, Paul S. Willen, and Vincent W. Yao. "Foreclosure Externalities: Some New Evidence." Working Paper No. 12-5. Federal Reserve Bank of Boston, September, 2012. http://www.nber.org/papers/w18353.

Gerardi, Kristopher S., Christopher L. Foote, and Paul Willen. "Reasonable People Did Disagree: Optimism and Pessimism About the U.S. Housing Market Before the Crash." Public Policy Discussion Paper No. 10-5. Federal Reserve Bank of Boston, September, 2010. https://www.bostonfed.org/economic/ppdp/2010/ppdp1005.pdf.

Ghent, Andra C., Ruben Hernandez-Murillo, and Michael T. Owyang. "Differences in Subprime Loan Pricing Across Races and Neighborhoods." Working Paper 2011-033C. Federal Reserve Bank of St Louis, March, 2014. http://research.stlouisfed.org/wp/2011/2011033.pdf.

------, and Marianna Kudlyak. "Recourse and Residential Mortgage Default: Evidence from U.S. States." Review of Financial Studies 24 (September 2011): 3139-3186. 
Gibb, Kenneth, and Christine Whitehead. "Towards the More Effective Use of Housing Finance and Subsidy." Housing Studies 22 (March 2007): 183-200.

Glaeser, Edward L., Joshua D. Gottlieb, and Joseph Gyourko. "Can Cheap Credit Explain the Housing Boom?" In Housing and the Financial Crisis, edited by Edward Glaeser and Todd Sinai, 301-360. Chicago, National Bureau of Economic Research, 2013.

------, Joseph Gyourko, and Albert Saiz. "Housing Supply and Housing Bubbles." Journal of Urban Economics 64 (September 2008): 198-217.

Glaeser, Edward, and Joseph Gyourko. "Urban Decline and Durable Housing." Journal of Political Economy 113, no. 2 (2005): 345-375.

Goodman, Allen C. "Is There an S in Urban Housing Supply? Or What on Earth Happened in Detroit?" Journal of Housing Economics 22 (September 2013): 179-191.

Green, Richard K., and Susan M. Wachter. "The American Mortgage in Historical and International Context." Journal of Economic Perspectives 19 (Fall 2005): 93-114.

Greenspan, Alan, and James Kennedy. "Sources and Uses of Equity Extracted from Homes." Oxford Review of Economic Policy 24 (Spring 2008): 120-44.

Gyourko, Joseph, and Raven Molloy. "Regulation and Housing Supply." Working Paper. Wharton School, July, 2014.

------, and Todd Sinai. "The (Un) changing Geographical Distribution of Housing Tax Benefits: 1980-2000." Tax Policy and the Economy (2004).

------, and Joseph Tracy. "Using Home Maintenance and Repairs to Smooth Variable Earnings." Review of Economics and Statistics 88 (November 2006): 736-747.

Hanson, Andrew, Zackary Hawley, Hal Martin, and Bo Liu. "Experimental Tests for Discrimination by Mortgage Loan Originators." Working Paper. Marquette University, 2013. https://editorialexpress.com/cgibin/conference/download.coi?db_name=UEA2013\&paper_id=93.

Harding, John C., C.F. Sirmans, and Stuart S. Rosenthal. "Depreciation of Housing Capital, Maintenance, and House Price Inflation." Journal of Urban Economics 61 (March 2007): 193217.

Harding, John, and Stuart S. Rosenthal. "Homeowner-Entrepreneurs, Housing Capital Gains, and Self-Employment." Working Paper. University of Connecticut, September, 2013. https://www.google.com/\#q=homeownerentrepreneurs $\% 2 \mathrm{C}+$ housing + capital + gains $\% 2 \mathrm{C}+$ and + self-employment.

Hartley, Daniel. "The Effect of Foreclosures on Nearby Housing Prices: Supply or Disamenity?" Working Paper 10-11R. Federal Reserve Bank of Cleveland, May, 2011. https://www.clevelandfed.org/Community_Development/events/PS2010/presentations_p apers/Hartley_paper.pdf.

Haughwout, Andrew, Donghoon Lee, Joseph Tracy, and Wilbert van der Klaauw. "Real Estate Investors, the Leverage Cycle, and the Housing Market Crisis." Staff Report No. 514. Federal Reserve Bank of New York, September, 2012. http://www.newyorkfed.org/research/staff_reports/sr514.pdf.

-----, Christopher Mayer, and Joseph Tracy. "Subprime Mortgage Pricing: The Impact of Race, Ethnicity, and Gender on the Cost of Borrowing." In Brookings-Wharton Papers on Urban Affairs, edited by Gary Burtless and Janet Rothenberg Pack, 33-63. Washington DC, Brookings, 2009.

------, Richard Peach, and Joseph Tracy. "Juvenile Delinquent Mortgages: Bad Credit or Bad Economy." Journal of Urban Economics 64 (September 2008): 246-257.

------, Richard Peach, and Joseph Tracy. "The Homeownership Gap." Current Issues in Economics and Finance 16 (May 2010): 1-11. 
------, Sarah Sutherland, and Joseph Tracy. "Negative Equity and Housing Investment." Staff Report No. 636. Federal Reserve Bank of New York, September, 2013.

http://www.newyorkfed.org/research/staff_reports/2013.html.

Haurin, Donald, Chao Ma, Stephanie Moulton, Maximilian D.Seligman Schmeiser, Jason S., and Shi Wei. "Spatial Variation in Reverse Mortgages Usage: House Price Dynamics and Consumer Selection." Working Paper. Ohio State University, 2014.

Herbert, Christopher E., Daniel T. McCue, and Rocio Sanchez-Moyano. "Is Homeownership Still an Effective Means of Building Wealth for Low-Income and Minority Households? Was it Ever?" In Homeownership Built to Last, edited by Eric S. Belskey, Christopher E. Herbert and Jennifer H. Molinsky. Brookings Institution Press, 2014.

Hilber, Christian A., and Yingchun Liu. "Explaining the Black-White Homeownership Gap: The Role of Own Wealth, Parental Externalities and Locational Preferences." Journal of Housing Economics 17 (June 2008): 152-174.

Hilber, Christian A.L., and Christopher Mayer. "Why Do Households Without Children Support Local Public Schools? Linking House Price Capitalization to School Spending." Journal of Urban Economics 65 (January 2009): 74-90.

------, and Tracy M. Turner. "The Mortgage Interest Dedution and its Impact on Homeownership Decisions." Review of Economics and Statistics (forethcoming) (2014).

Himmelberg, Charles, Christopher Mayer, and Todd Sinai. "Assessing High House Prices: Bubbles, Fundamentals and Misperceptions." Journal of Economic Perspectives 19 (Fall 2005): 67-92.

Hunter, William C., and Mary Beth Walker. "The Cultural Affinity Hypothesis and Mortgage Lending Decisions." Journal of Real Estate Finance and Economics 13 (July 1996): 57-70.

Hurst, Erik, and Annamaria Lusardi. "Liquidity Constraints, Household Wealth, and Entrepreneurship." Journal of Political Economy 112 (April 2004): 319-347.

Immercgluck, Dan, and Geoff Smith. "The External Costs of Foreclosure: The Impact of SingleFamily Mortgage Foreclosure on Property Values." Housing Policy Debate 17, no. 1 (2006): 5779.

Immergluck, Dan, and Geoff Smith. "The Impact of Single-Family Mortgage Foreclosures on Neighborhood Crime." Housing Studies 21 (November 2006): 851-866.

Integrated Financial Engineering. Actuarial Review of the Federal Housing Administration Mutual Mortgage Insurance Fund HECM Loans for Fiscal Year 2012, 2012.

Jones, Lawrence D. "Deficiency Judgments and the Exercise of the Default Option in Home Mortgage Loans." Journal of Law and Economics 36 (April 1993): 115-138.

Keenan, Teresa A. "Home and Community Preferences of the 45+ Population." Working Paper. AARP, November, 2010. http://assets.aarp.org/rgcenter/general/home-communityservices-10.pdf.

Kiff, John. "Canadian Residential Mortgage Markets: Boring But Effective?" Working Paper 09/130. IMF, June, 2009.

Ladd, Helen F. "Evidence on Discrimination in Mortgage Lending." Journal of Economic Perspectives 12 (Spring 1998): 41-62.

Lea, Michael. "International Comparison of Mortgage Product Offerings." Special Report. Research Institute for Housing America, July, 2010.

Lee, Donghoon, Christopher Mayer, and Joseph Tracy. "A New Look at Second Liens." In Housing and the Financial Crisis, edited by Edward L. Glaeser and Todd Sinai, 205-234. Chicago, The University of Chicago Press, 2013.

Lovenheim, Michael F. "The Effect of Liquid Housing Wealth on College Enrollment." Journal of Labor Economics 29 (October 2011): 741-771. 
Lubell, Jeffrey. "Filling the Void Between Homeownership and Rental Housing: A Case For Expanding the Use of Shared Equity Homeownership." In Homeownership Built to Last, edited by Eric S. Belsky, Christopher E. Herbert and Jennifer H. Molinsky. Brookings Institution Press, 2014.

Lutz, Byron, Raven Molloy, and Hui Shan. "The Housing Crisis and State and Local Government Tax Revenue: Five Channels." Regional Science and Urban Economics 41 (July 2011): 306-319. Mayer, Christopher, and Karen Pence. "Subprime Mortgages: What, Where, and to Whom?" In Housing Markets and the Economy: Risk, Regulation, and Policy: Essays in honor of Karl E. Case, edited by Edward L. Glaeser and John M. Quigley, 149-196. Cambridge, Lincoln Institute of Land Policy, 2009.

------, Karen Pence, and Shane M. Sherlund. "The Rise in Mortgage Defaults." Journal of Economic Perspectives 23 (Winter 2009): 27-50.

Melzer, Brian T. "Mortgage Debt Overhang: Reduced Investment by Homeowners with Negative Equity." Working Paper. Northwestern University, Kellogg School of Management, August, 2012.

http:/ / citeseerx.ist.psu.edu/viewdoc/download?doi=10.1.1.412.7932\&rep=rep1\&type=pdf.

Mian, Atif, and Amir Sufi. "The Consequences of Mortgage Credit Expansion: Evidence from the U.S. Mortgage Default Crisis." Quarterly Journal of Economics 124 (Nov 2009): 1449-1496.

-----, and Amir Sufi. "House Prices, Home Equity-Based Borrowing, and the U.S. Household Leverage Crisis." American Economic Review 101 (August 2011): 2132-2156.

Molloy, Raven, and Hui Shan. "The Postforeclosure Experience of U.S. Households." Real Estate Economics 41 (Summer 2013): 225-254.

Morgan, Donald, Benjamin Iverson, and Matthew Botsch. "Subprime Foreclosures and the 2005 Bankruptcy Reform." Economic Policy Review 18 (August 2012): 47-57.

Moulton, Stephanie, Donald R. Haurin and Wei Shi. "An Analysis of Default Risk in the Home Equity Conversion Mortgage (HECM) Program." Working Paper. Ohio State University, 2014. http://ssrn.com/abstract $=2468247$

Munnell, Alicia H., Geoffrey M.B. Tootell, Lynne E. Browne, and James McEneaney. "Mortgage Lending in Boston: Interpreting HMDA Data." American Economic Review 86 (March 1996): 25-53.

National Association of Realtors. Housing Pulse Survey, 2013.

National Consumer Law Center. "The Other Foreclosure Crisis: Property Tax Lien Sales," July 14, 2012. https://www.nclc.org/issues/the-other-foreclosure-crisis.html.

Nenov, Plamen. "Labor Market and Regional Reallocation Effects of Housing Busts." Working Paper. MIT, 2010.

OCC Mortgage Metrics Report: Fourth Quarter 2013. Comptroller of the Currency, US Department of the Treasury, December, 2013.

Office of Management and Budget. Analytical Perspectives. Government Printing Office, 2014.

O'Flaherty, Brendan. "Abandoned Buildings: A Stochastic Analysis." Journal of Urban Economics 34 (July 1993): 43-74.

Palmer, Christopher. "Why Did So Many Subprime Borrowers Default During the Crisis: Loose Credit or Plummeting Prices." Working Paper. MIT, January, 2014.

Pinto, Edward. How the FHA Hurts Working Class Families and Communities. AEI, 2012.

Poterba, James, and Todd Sinai. "Tax Expenditures for Owner-Occupied Housing: Deductions for Property Taxes and Mortgage Interest and the Exclusion of Imputed Rental Income." American Economic Review 98 (May 2008): 84-89.

-----, Steven Venti, and David Wise. "The Composition and Drawdown of Wealth in Retirement." Journal of Economic Perspectives 25 (Fall 2011): 95-118. 
Quigley, John M. "Interest Rate Variations, Mortgage Prepayments and Household Mobility." Review of Economics and Statistics 69 (November 1987): 636-643.

Refinance Report Fourth Quarter 2013. Federal Housing Finance Agency, 2013.

Ross, Stephen L., Margery Austin Turner, Erin Godfrey, and Robin R. Smith. "Mortgage Lending in Chicago and Los Angeles: A Paired Testing Study of the Pre-application Process." Journal of Urban Economics 63 (May 2008): 902-919.

Ross, Stephen, and John Yinger. The Color of Credit: Mortgage Lending Discrimination, Research Methodology, and Fair Lending Enforcement. Cambridge, MIT Press, 2002.

Saiz, Alberto. "On Local Housing Supply Elasticity." Working Paper. University of Pennsylvania, The Wharton School, 2008. http://papers.ssrn.com/so13/papers.cfm?abstract_id=1193422.

Scafidi, Benjamin P. "An Economic Analysis of Housing Abandonment." Journal of Housing Economics 7 (December 1998): 287-303.

Schill, Michael H., and Susan M. Wachter. "A Tale of Two Cities: Racial and Ethnic Geographic Disparities in Home Mortgage Lending in Boston and Philadelphia." Journal of Housing Research 4, no. 2 (1993): 245-275.

Schuetz, Jenny, Vicki Been, and Ingrid Gould Ellen. "Neighboring Effects of Concentrated Mortgage Foreclosures." Journal of Housing Research 17 (December 2008): 306-319.

Schulhofer-Wohl, Sam. "Negative Equity Does Not Reduce Homeowners' Mobility." Working Paper No. 16701. NBER, January, 2011. http://www.nber.org/papers/w16701.

Shan, Hui. "Reversing the Trend: The Recent Expansion of the Reverse Mortgage." Real Estate Economics 39 (Winter 2011): 743-768.

Shiller, Robert. The Subprime Solution: How Today's Global Financial Crisis Happened, and What to Do About It. Princeton, NJ, Princeton University Press, 2008.

-----. "Why is Hou8sing Finance Still Stuck in Such a Primitive Stage?" American Economic Review 104 (May 2014): 73-76.

Stein, Jeremy. "Prices and Trading Volume in the Housing Market: A Model with Down-Payment Effects." Quarterly Journal of Economics 110 (May 1995): 379-406.

Tootell, Geoffrey M.B. "Redlining in Boston: Do Mortgage Lenders Discriminate against Neighborhoods?" Quarterly Journal of Economics 111 (November 1996): 1049-1079.

Traclet, Virginia. "An Overview of the Canadian Housing Finance System." Housing Finance International, Autumn 2010, 6-13.

Turner, Margery Austin, Rob Santos, Diane K. Levy, Doug Wissoker, Claudia Aranda, and Rob Pitingolo. "Housing Discrimination Against Racial and Ethnic Minorities 2012." Research Report. U.S. Department of Housing and Urban Development, Office of Policy Development, June, 2013.

U.S. Department of Housing and Urban Development. "Measuring the Costs and Savings of Aging in Place." Evidence Matters, Fall 2013.

Valletta, Robert G. "House Lock and Structural Unemployment." Labour Economics 25 (December 2013): 86-97.

White, Michelle J. "Property Taxes and Urban Housing Abandonment." Journal of Urban Economics 20 (November 1986): 312-330.

Wilson, Ellen, and Robert R. Callis. "Who Could Afford to Buy a Home in 2009?" Working Paper, 2013. http://www.census.gov/prod/2013pubs/h121-13-02.pdf.

Woodward, Susan E., and Robert E. Hall. "Diagnosing Consumer Confusion and Sub-optimal Shopping Effort: Theory and Mortgage-Market Evidence." American Economic Review 102 (December 2012): 3249-3276.

Zhu, Jun. "An Empirical Analysis of the Home Affordable Refinance Program's Impact on Default Rates." Working Paper. Freddie Mac, May, 2012. 
Table 1. Combined LTV ratio at origination

\begin{tabular}{|c|c|c|c|c|c|c|c|c|}
\hline \multirow[b]{2}{*}{ Percentile: } & \multicolumn{4}{|c|}{ All Housing Purchases ${ }^{1}$} & \multicolumn{4}{|c|}{ Nonprime Purchase Mortgages $^{2}$} \\
\hline & $25^{\text {th }}$ & $50^{\text {th }}$ & $75^{\text {th }}$ & $90^{\text {th }}$ & $25^{\text {th }}$ & $50^{\text {th }}$ & $75^{\text {th }}$ & $90^{\text {th }}$ \\
\hline 2004 & 56 & 80 & 95 & 100 & 80 & 95 & 100 & 100 \\
\hline 2005 & 64 & 86 & 99 & 100 & 80 & 95 & 100 & 100 \\
\hline 2006 & 70 & 90 & 100 & 100 & 90 & 99 & 100 & 100 \\
\hline
\end{tabular}

${ }^{1}$ Source: Glaeser et al (2010). DataQuick data from 89 metro areas.

${ }^{2}$ Source: LoanPerformance data on securitized non-prime mortgages 
Figure 1. Homeownership rate

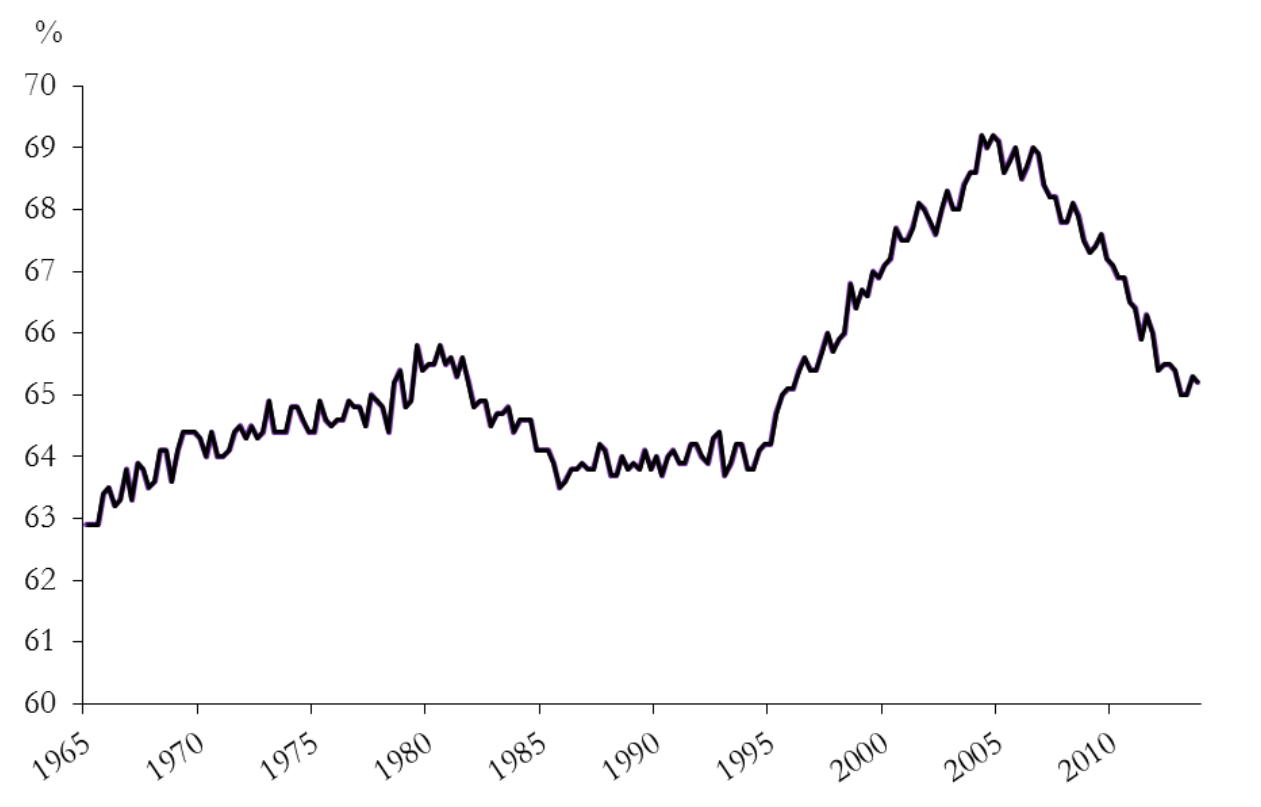

Source: U.S. Census Bureau, Current Population / Housing Vacancy Survey, Series H-111. Fraction of housing units that are owner-occupied

Figure 2. Fraction of homeowners with a mortgage

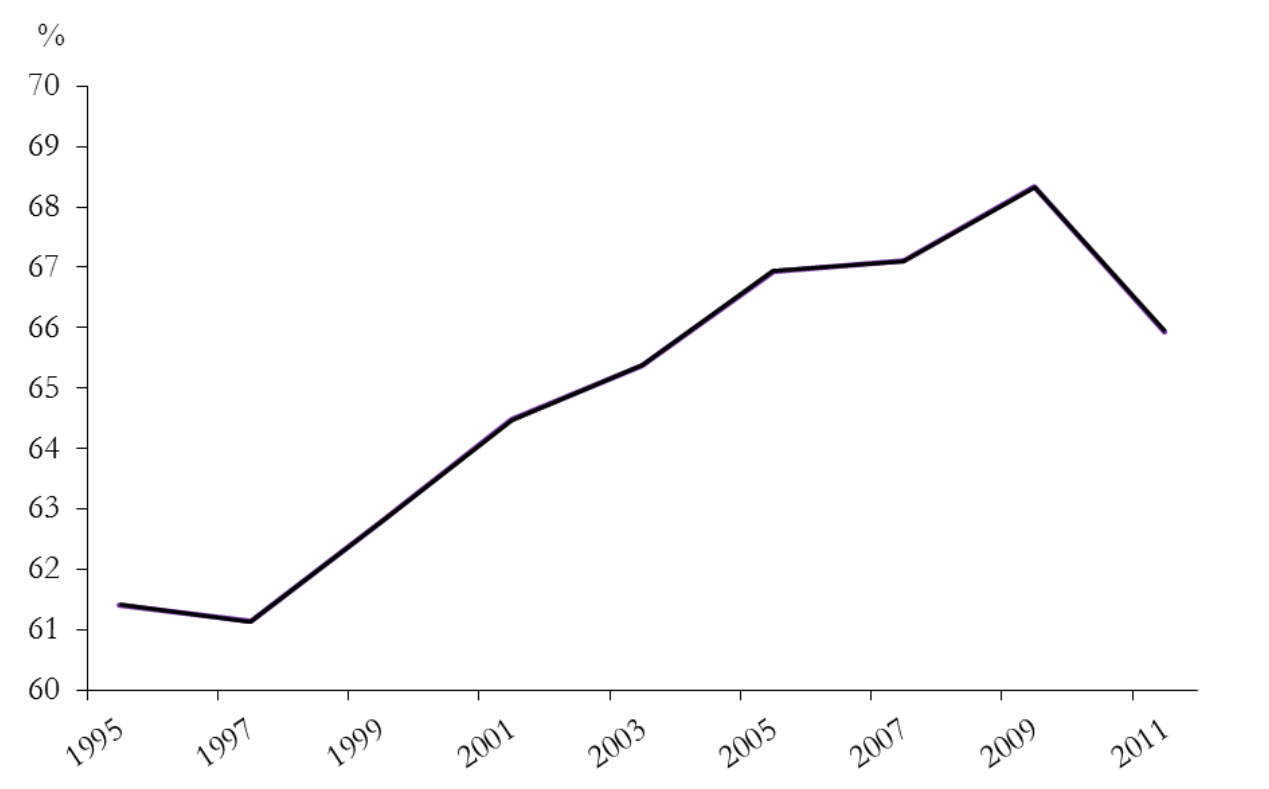

Source: U.S. Census Bureau, Current Housing Reports, Series H150/01,

American Housing Survey. Fraction of owner-occupied housing units with a mortgage 
Figure 3. Mortgages and HELOCs

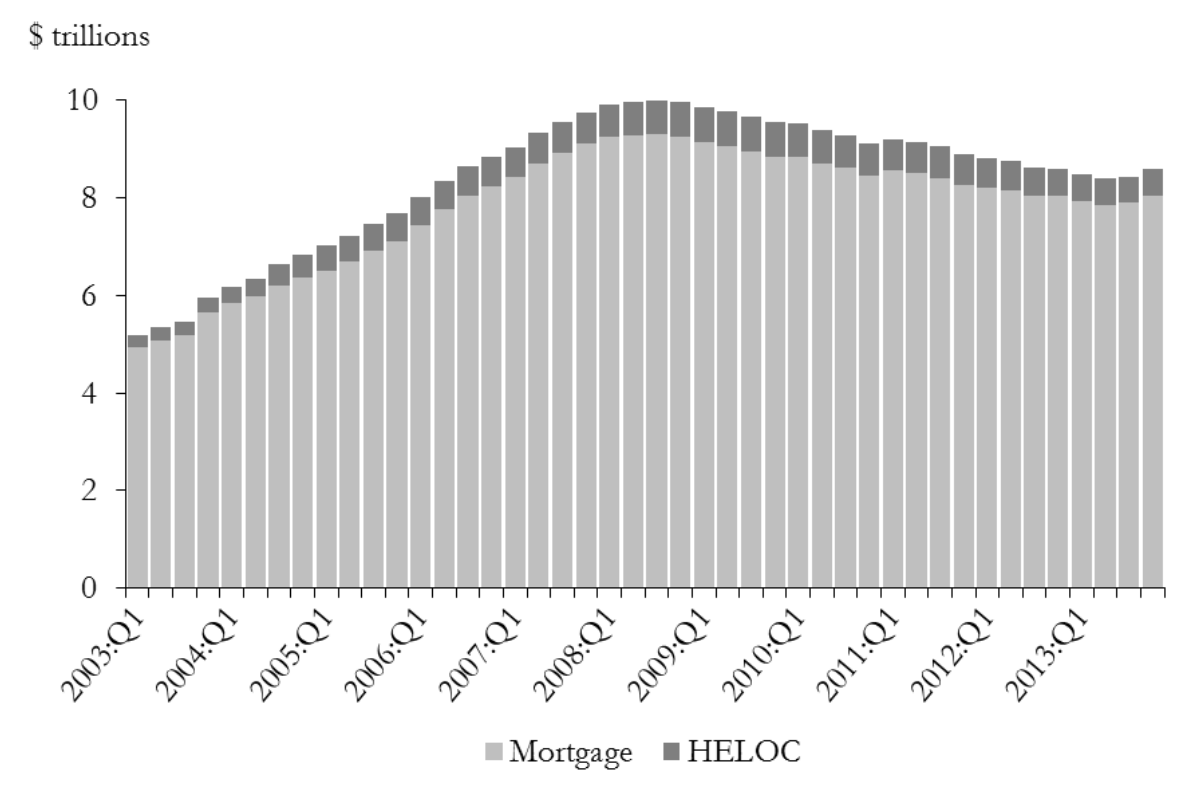

Source: FRBNY Consumer Credit Panel

Figure 4. Housing market demand and supply

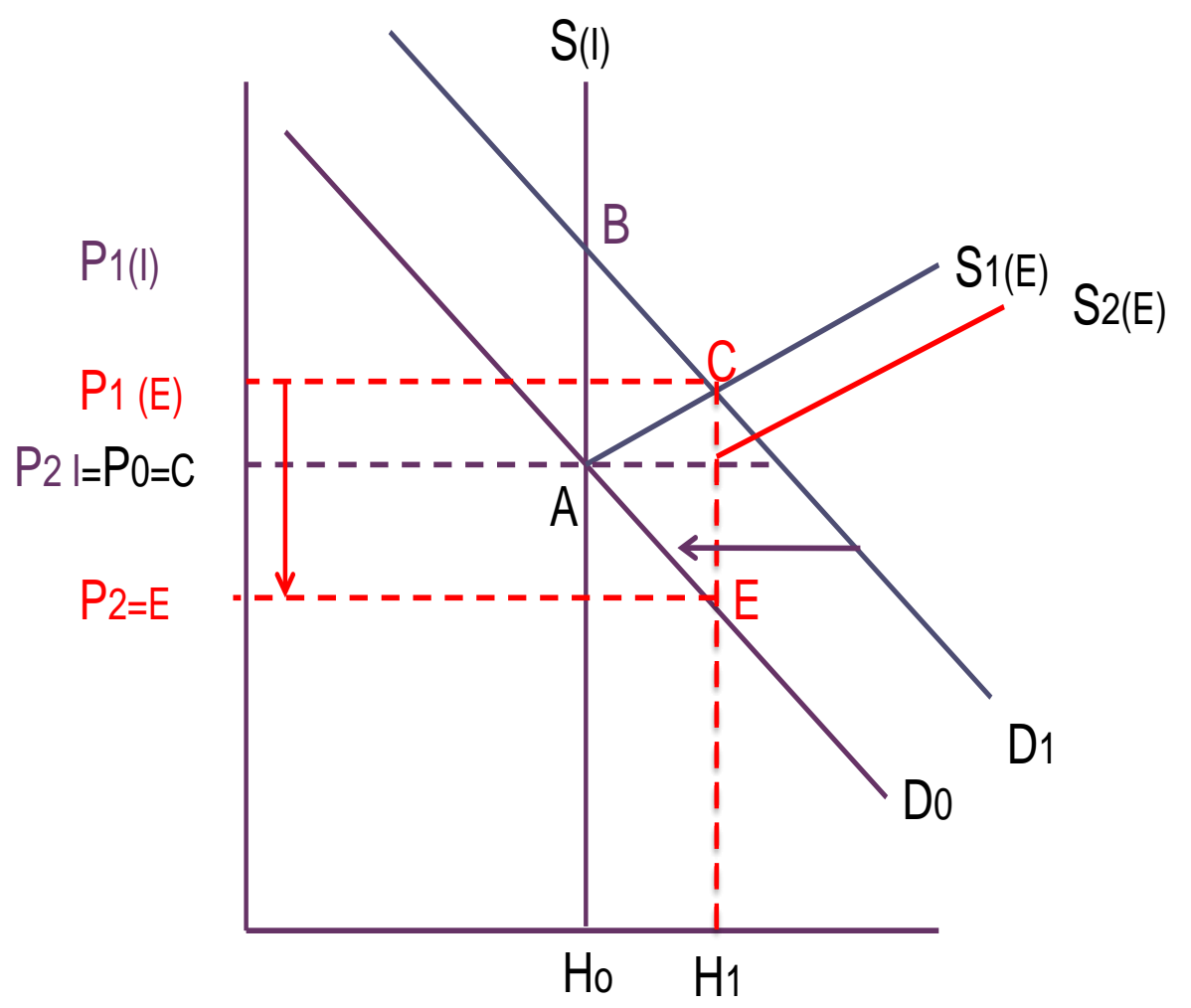


Figure 5. Housing market demand and supply - with abandonment

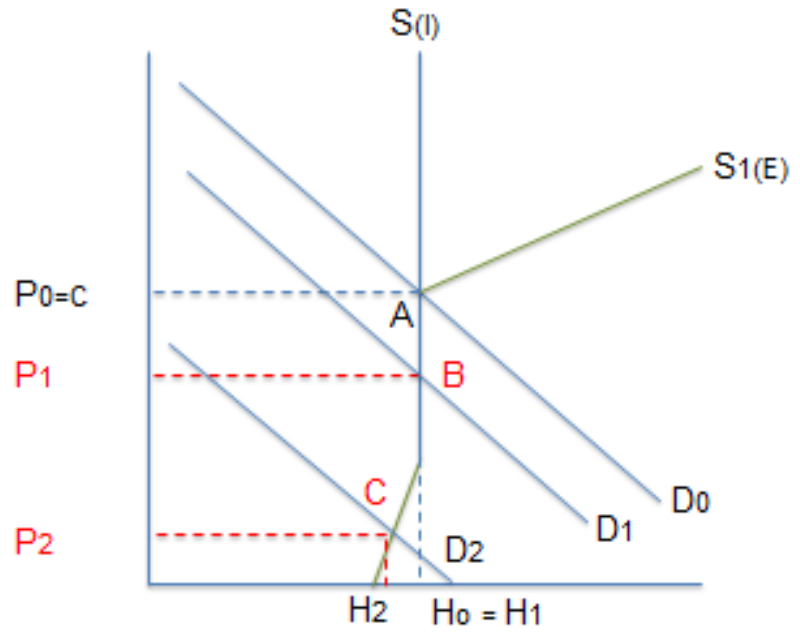

Figure 6. Homeownership rate by race and ethnicity

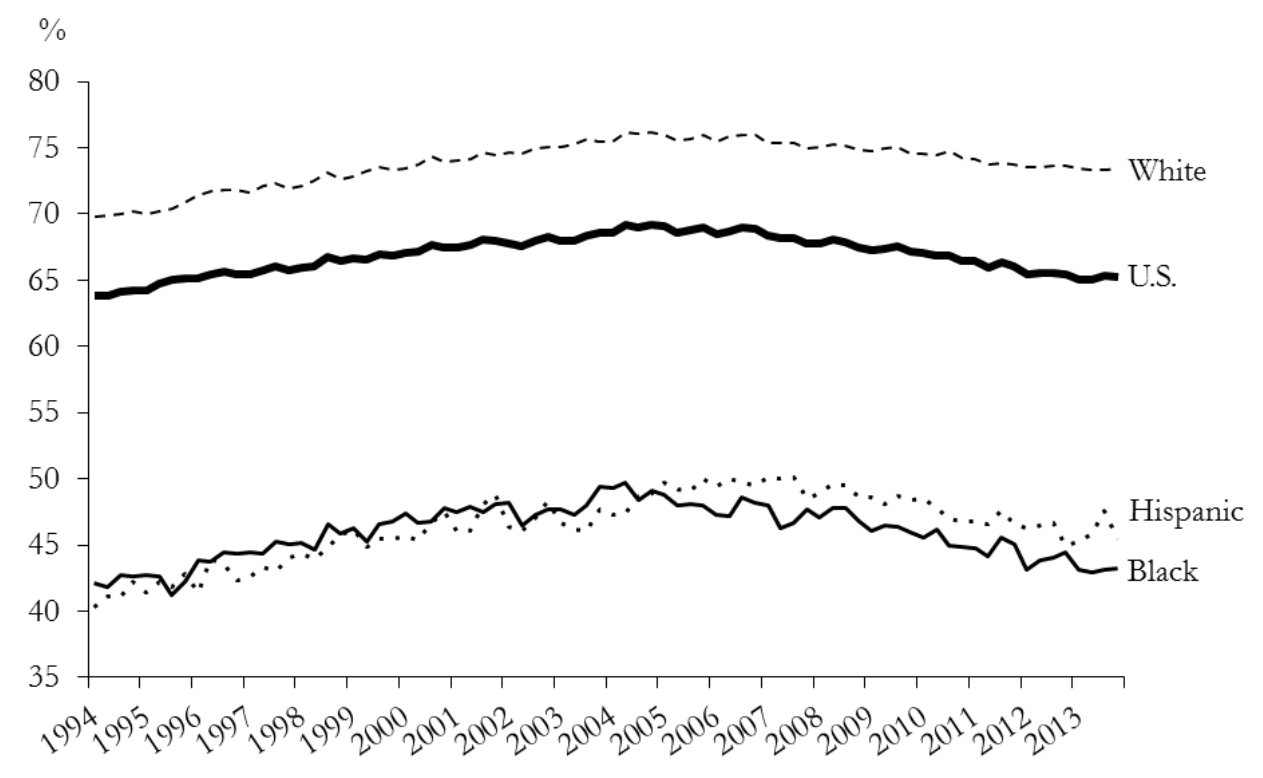

Source: U.S. Census Bureau, Current Population Survey/Housing Vacancy Survey, Series H-111. Race and ethnicity of householder: "White" is non-Hispanic white, "Black" is non-Hispanic black, "Hispanic" can be of any race. 
Figure 7. Fraction of mortgages that is subprime

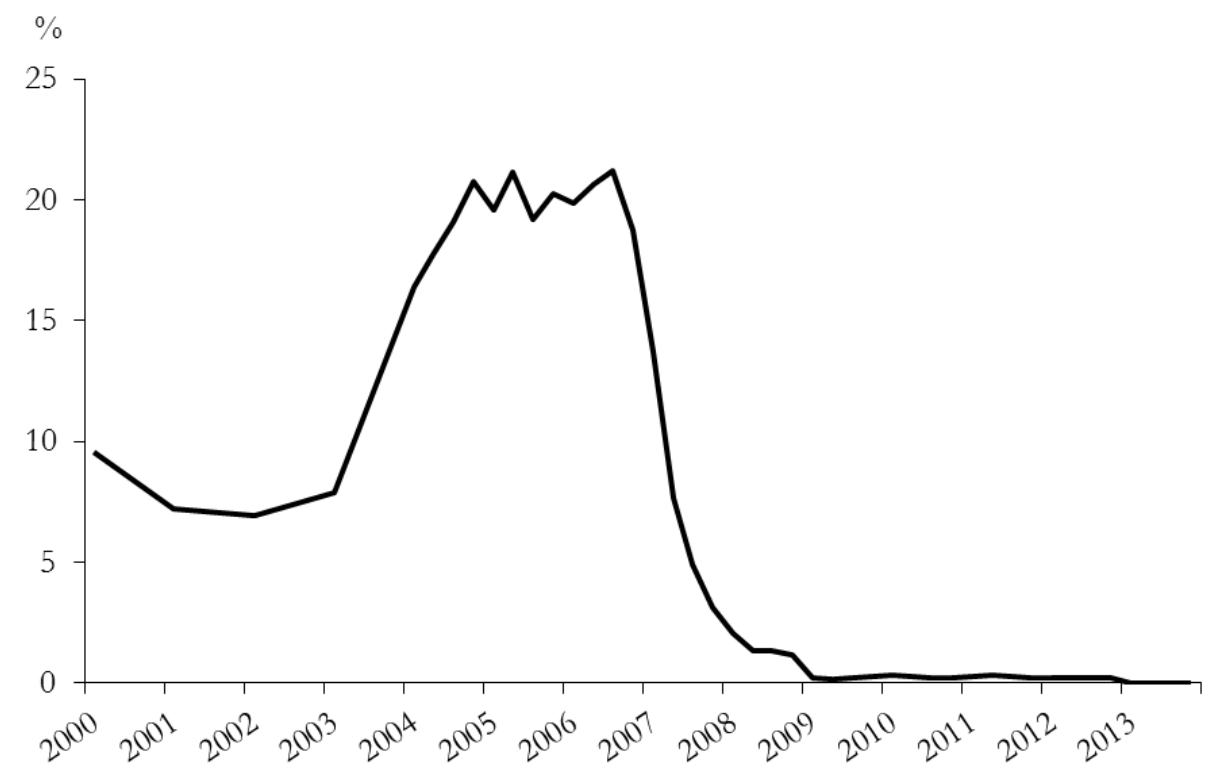

Source: Inside Mortgage Finance, 2013. Weighted by mortgage balance.

Figure 8. Distribution of higher cost mortgages in NYC, by census tract race and ethnicity

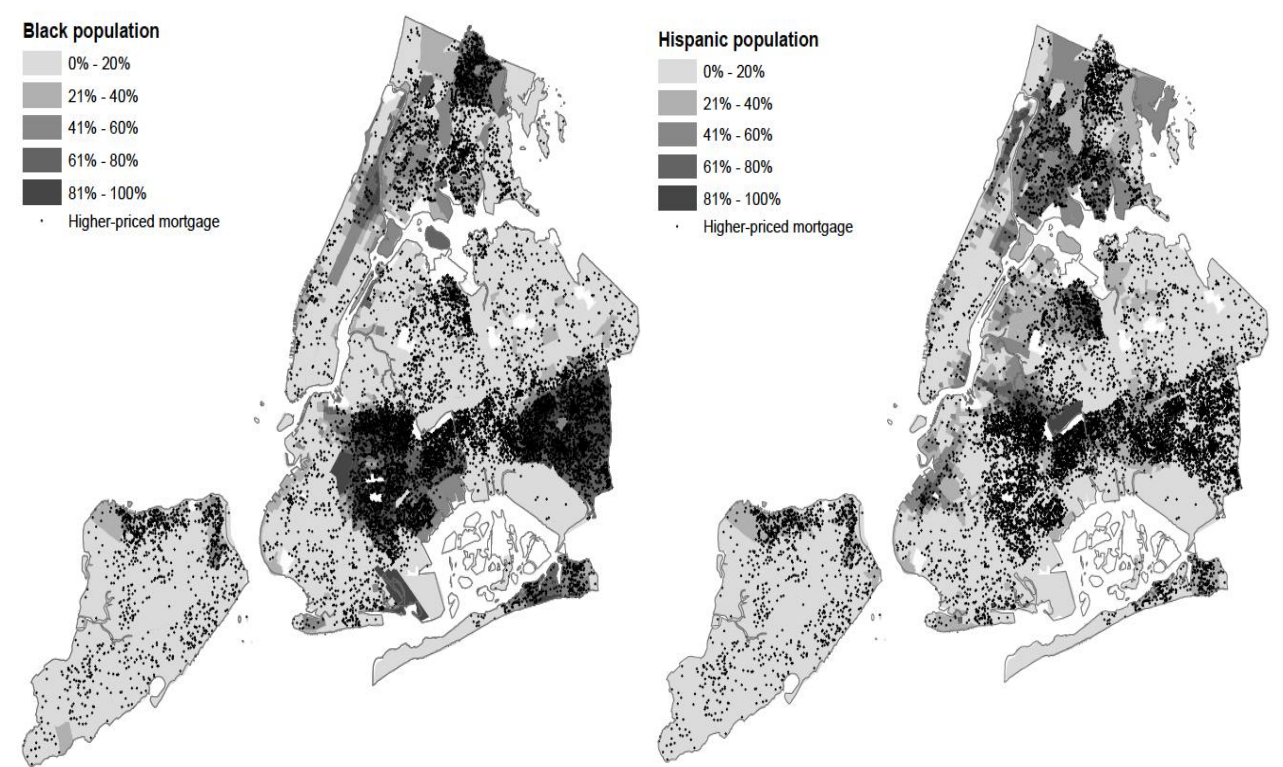

Source: U.S. Census 2000 and HMDA 2006. Each dot represents one higher-priced mortgage origination (first lien, owner-occupied home purchase), randomly located within its census tract. Shading shows the fraction of non-Hispanic blacks, and fraction Hispanics of any race among each tract's population.

Figure 9. Homeownership and mortgage over the lifecycle 


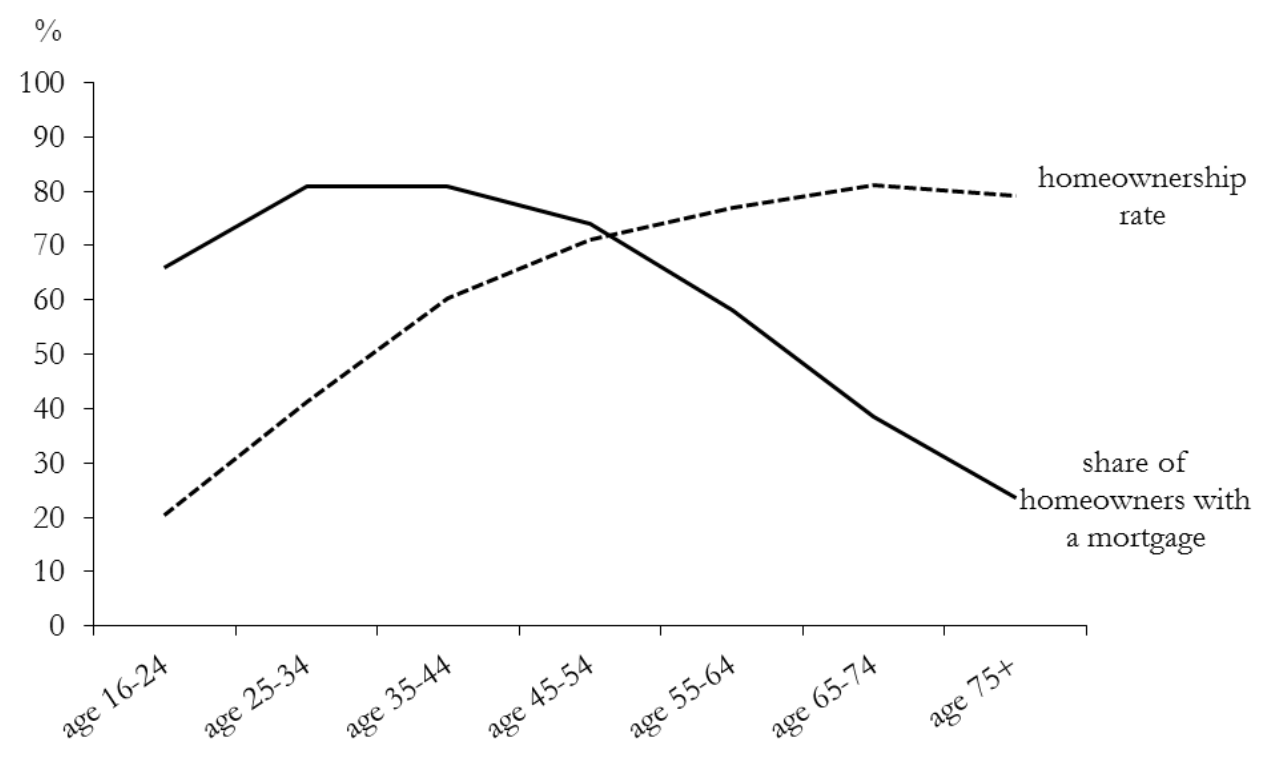

Source: Current Population Survey, March 2013

Figure 10. Fraction of mortgages with negative equity

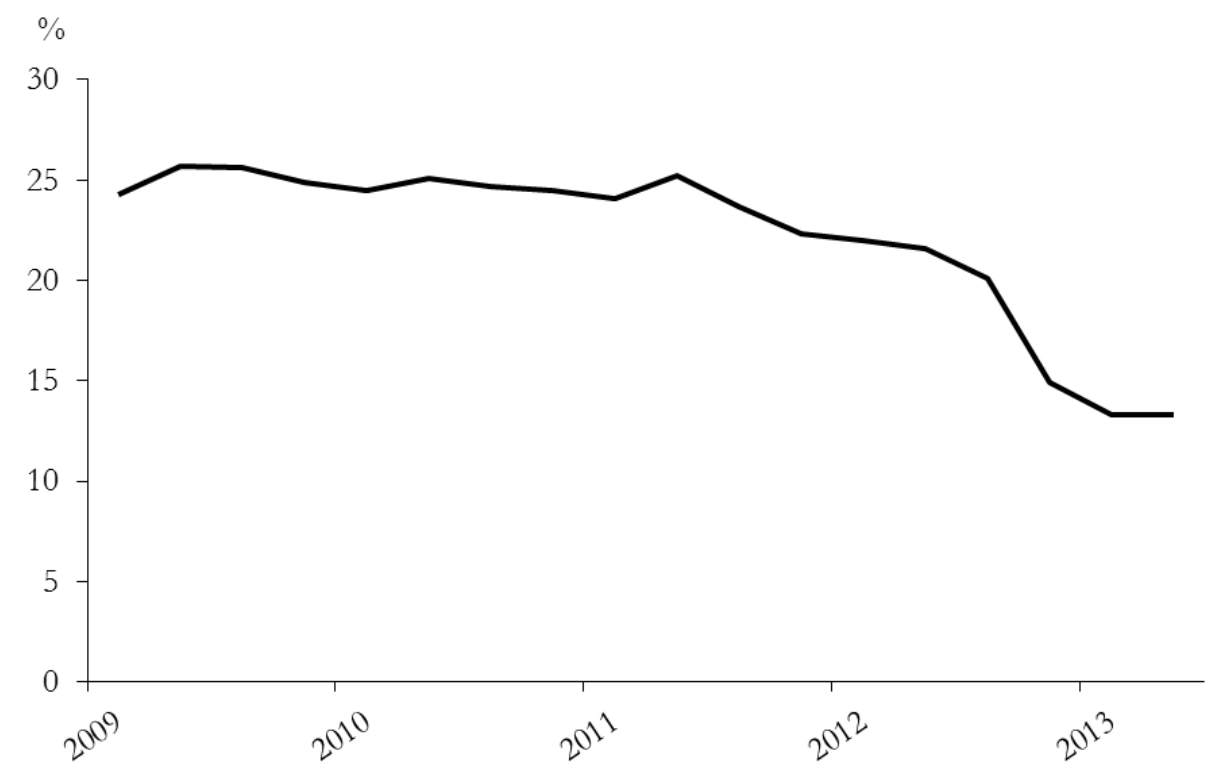

Source: CoreLogic. Fraction of mortgages where the debt outstanding is greater than the estimated property value. 
Figure 11. Fraction of mortgaged homes in foreclosure

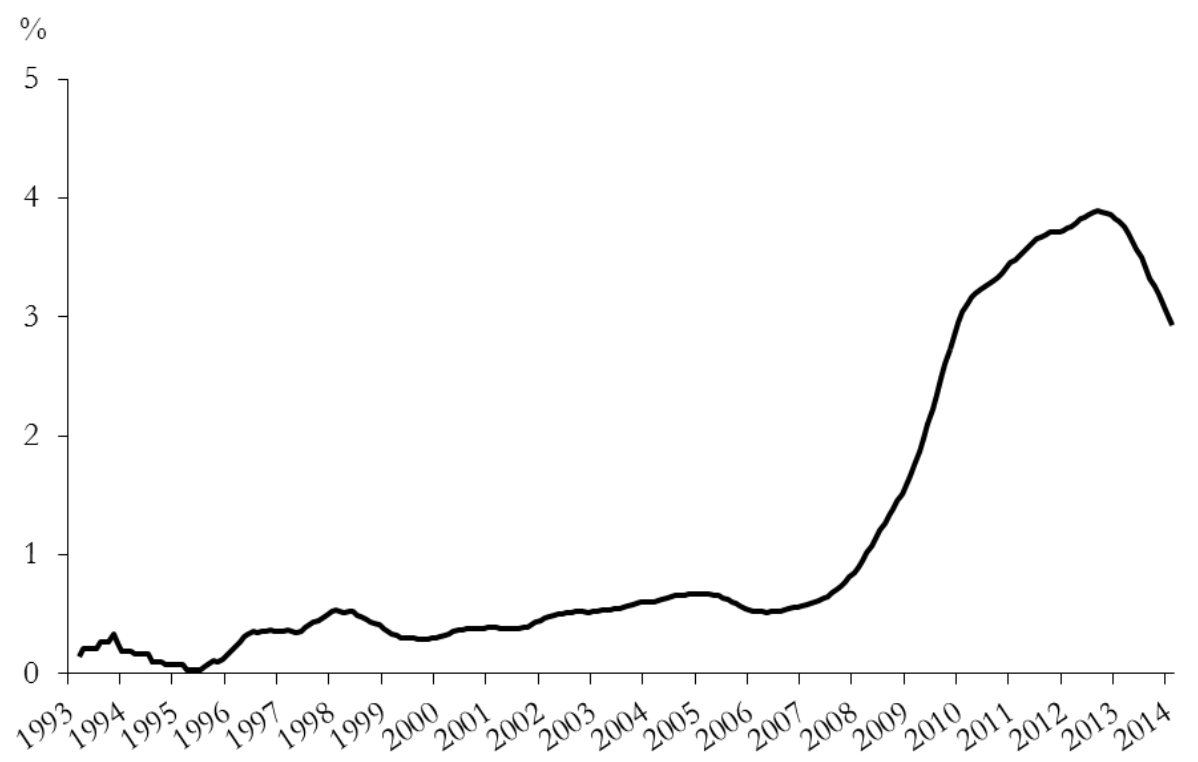

Source: Lender Processing Services. First-lien, owner-occupied purchase mortgages.

Figure 12. Distribution of foreclosure filings in NYC, by census tract race and ethnicity

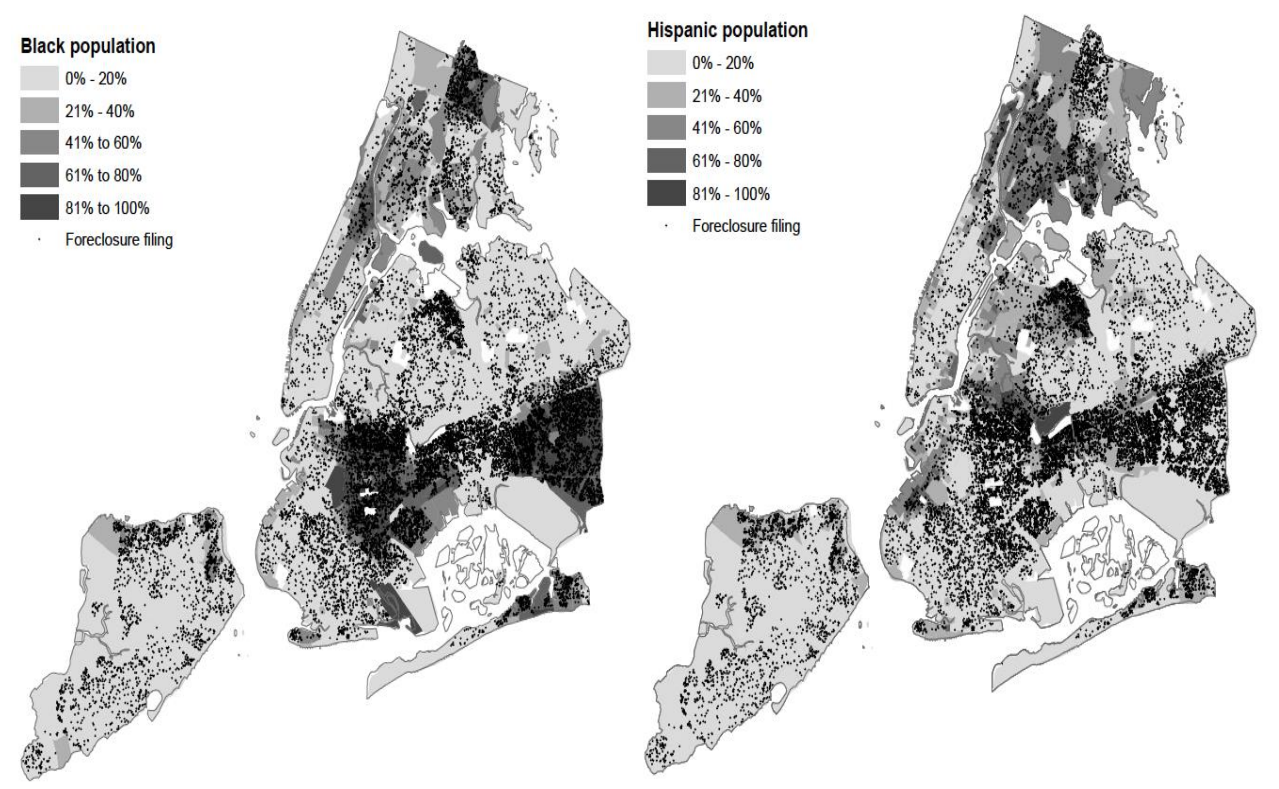

Source: U.S. Census 2000 and Public Data Corporation 2009. Each dot represents one Residential foreclosure filing (lis pendens). Shading shows the fraction of non-Hispanic blacks and the fraction of Hispanics of any race among each tract's population. 